\title{
Las otras rebeliones: cultura popular e independencias
}

Luis Miguel Glave

Universidad Pablo de Olavide

Este artículo comenta los avances historiográficos sobre la participación popular en la independencia mexicana y la cultura política de la época. Toma como punto de partida los aportes de Eric Van Young en su libro The Other Rebellion y el debate que se abrió a partir de su publicación. Discute, además, la aceptación o no de un "giro cultural" en los estudios históricos sobre América Latina y compara el proceso político mexicano con el de los Andes a partir de los aportes más recientes al respecto. Postula, por último, la necesidad de explorar el mundo simbólico y cultural de los indios y la plebe que participa en las movilizaciones políticas y militares, en tantas "otras rebeliones" producto de un momento de cambio y crisis general en la sociedad colonial.

PALABRAS CLAVE: Independencia, cultura política, historia cultural, rebeliones indígenas, historiografía, México, región andina.

This article comments on historiographical developments pertaing to popular participation during the Independence of Mexico and on the political culture of the period. Its point of departure is the argument advanced by Eric Van Young in his book The Other Rebellion (2001) and the debate sparked by its publication. The article also discusses wether or not a "cultural turn" may be said to characterize historical studies of Latin America and compares the political process in Mexico with that of the Andes. It is suggested that we need to take into account, too, the symbolic and cultural world of both Indians and commoners who participated in the political and military actions of "other rebellions", the outcome of a time of change and general crisis in colonial society.

KEYWORDS: Independence, political culture, cultural history, Indian rebellions, historiography, Mexico, the Andes.

La publicación en español del libro de Eric Van Young, The Other Rebellion, es motivo para comentar tanto los muchos temas que a partir de ese trabajo se desprenden para la agenda de la historiografía latinoamericana, como la polémica que — con razón, vista la importancia de la obraha suscitado (y que ya ha circulado antes de su aparición en este idioma). ${ }^{1}$

1 Van Young, Eric: The Other Rebellion. Popular Violence, Ideology, and the Mexican Struggle for Independence, 1810-1821, Stanford University Press, XVII, Stanford, 2001, pág. 702; Knight, Alan: "Eric Van Young, The Other Rebellion y la historiografía mexicana", Historia Mexicana, 214, 2004, págs. 445-516; Van Young, Eric: "De aves y estatuas: respuesta a Alan Knight", Historia Mexicana, 214, 2004, págs. 517-574 . 
Se trata de un trabajo mayor, hecho por un historiador de larga trayectoria - no es la publicación de una tesis o de un primer trabajo que tiene siempre la entrega del inicio y los límites de la falta de práctica- que nos presenta una forma de hacer historia y un punto de quiebre para las visiones de una época que conoce muy bien desde hace mucho tiempo. Se trata nada menos que de la era de las luchas que llevaron a la emancipación o independencia política de la Nueva España. Incluso considerando la conquista o invasión del continente, no hay en las historias nacionales latinoamericanas otro tema que tenga más entidad, que sea más polémico y movilizador de sentimientos y que por ello vaya a ser permanente, como "momento" de historia, de identidad, de representaciones sociales, que el de las independencias.

\section{The Other Rebellion}

Lo que haremos en estas páginas es un comentario historiográfico, a partir de The Other Rebellion, para plantearnos las posibilidades y los límites de una agenda de trabajo acerca de "las otras rebeliones" posibles en el vasto y múltiple escenario de la América hispana. No es necesario reseñar el libro de Van Young que ha sido ya comentado ampliamente, ni glosar la larga polémica que mantiene con Alan Knight, ${ }^{2}$ se trata de partir de ese importante juego de ideas para plantearnos algunos temas sobre el estudio de las independencias y la forma de hacer esa historia. Frente a este debate que se inscribe en una renovada y académica visión del proceso, tenemos un inmenso arsenal de publicaciones tanto de tinte nacionalista, de discursos canonizadores necesarios hasta un determinado momento en la conformación de las identidades nacionales, como las críticas que surgieron a raíz de los movimientos sociales, de "liberación nacional" y de lucha contra la injusta y centenaria forma de distribución de la riqueza y del poder, que se plantearon leer de otra forma las historias nacionales y condenar luego de juicio sumario a las burguesías, los liberalismos y los estados criollos que formaron los países de América Latina. Los estudios que se plantean renovar la historia de la ruptura con España y las formas que tenía la sociedad colonial, sus mecanismos de

2 Knight, Alan: "The Other Rebellion: Popular Violence, Ideology, and the Mexican Struggle for Independence, 1810-1821 (review)”, The Americas, vol. 59, núm. 4, abril 2003, págs. 606-611. 
cambio y las continuidades como los desafíos de la cultura poscolonial tienen la tarea de discernir el grano de la paja entre tanta publicación y leer nuevamente las fuentes y los testimonios, así como dotar a los continuadores de nuevas herramientas de comprensión y de elementos de juicio.

En ese panorama, no es extraño encontrar un trabajo exuberante, tanto por las dimensiones de la obra como por la forma de plantearse los problemas historiográficos como el de Van Young. Los temas giran en torno a historias locales, discursos no retomados y series estadísticas de más de un millar de acusados por infidencia entre 1810 y 1812 que, básicamente, le permiten analizar las formas de la participación y la violencia popular en las luchas por la independencia novohispana. Según el planteamiento central del libro, lo que se buscaba no era tanto la "liberación nacional" como la defensa de las identidades locales y los niveles de explotación en las relaciones más cara a cara de la vida local. Pero incluso tratando de poner esta sumilla como ilustrativa de las intenciones del autor, no se le hace justicia pues está claro que no es un "gran relato" de los sucesos lo que busca; justamente, lo que le reclama su crítico A. Knight. Usa una categoría muy sugerente, "full-face profile", muchas caras de un fenómeno, y mantiene esa estrategia de presentación al punto que si bien esto que resumimos calza con el postulado general, también se encarga de dejar tantas evidencias sobre las posibles formas de comportamiento diferente que no se le puede señalar como descuidado de otras posibles lecturas de los sucesos y los comportamientos.

Atisbando ya una polémica, Brian Hamnett ha señalado algo similar en su balance. Destaca Hamnett en la visión de Van Young la identificación de factores etnoculturales como motivación de la participación rural en la insurgencia de 1810. Separa la rebelión rural y popular de la insurrección liderada por los criollos, tiene una visión "dualista" que limita la idea de que los indios participaran en una liberación nacional, cuando lo que hicieron según este profundo estudio de caso fue defender su identidad comunal, reinterpretarse y enfrentarse a las fuerzas que erosionaban su relación con la economía y la política coloniales. El problema básico según Hamnett es la interpretación "comunalista" de la movilización rural, en desavenencia con una idea nacional o nacionalista. Entra pues en el género de las interpretaciones culturalistas de la mentalidad rural y en la importancia de lo local, que sólo usaba la gran ideología rebelde como revulsivo para encajar sus demandas, más propias a su defensa comunal. 
En esto, el breve comentario de Hamnett coincide con la larga evaluación de Knight. ${ }^{3}$

The Other Rebellion consta de 19 capítulos agrupados en tres partes: la primera retrata a los rebeldes como actor social de muchas y cambiantes caras y termina con el papel de los indios. La segunda se detiene en los líderes, tanto laicos - populares, incluso algunos delincuentes que se volvieron líderes como Chito Villagrán ${ }^{4}$ y nobles indios- como religiosos, a los que se dedican 100 de las 500 páginas de texto. Finalmente se aborda los actos de violencia y su lectura cultural, con particular énfasis en la palabra y el texto cultural; tres capítulos hacen la anatomía de rebeliones concretas. En esta última parte se analizan las formas de expresión política y lo confuso que podía ser el accionar rebelde de campesinos que se alzaban pensando que servían al rey y mataban españoles y las diversas formas de mesianismo que informaron el movimiento indio, tema sobre el que nos detendremos más adelante.

En cuanto a la doctrina y cultura popular, que es lo que quiere estudiar, su planteamiento podría relacionarse con los estudios de Ranahit Guha, ${ }^{5}$ mientras que se desmarca de Hobsbawn en Rebeldes primitivos, ${ }^{6}$ pues asegura que no hubo una "doctrina" o macropolítica que informara el conjunto de las movilizaciones campesinas. Pero nuevamente, aunque enfatiza en los múltiples movimientos populares y su diversidad, acepta y da señales de cómo algo de ese discurso entra en la esfera cotidiana del pueblo y, aunque no las formulen, sienten esas ideas, una política antirégimen que hay que rastrear a través de evidencias ambiguas de sus acciones y decires o expresiones orales: canciones, coplas, pasquines que se leen en público.

3 Hamnett, Brian: "Comentario" a Van Young, Journal of Latin American Studies, 34, 2002, págs. 962-965. Aunque insinúa otra visión del proceso, Hamnett es más receloso en cuanto al uso de categorías que piensa posmodernas que deben inspirar el título de "otra" y la mención a lo "subalterno". Se manifiesta abiertamente en desacuerdo con el capítulo referido al status mesiánico de la monarquía hispana.

4 Van Young: The Other..., págs. 179-200. lona, 2002.

5 Guha, Ranahit: Las voces de la historia y otros estudios subalternos, Crítica, Barce-

6 Hobsbawn, Eric: Rebeldes primitivos: estudio sobre las formas arcaicas de los movimientos sociales en los siglos XIX y XX, Crítica, Barcelona, 2001.

7 Van Young: The Other..., pág. 110. Algo similar he encontrado en los estudios que vengo haciendo sobre la revolución cuzqueña de 1814 y sus proyecciones. Glave, Luis Miguel: "La ilustración y el pueblo: el 'loco' Bernardino Tapia. Cambio y hegemonía cultural en los Andes al fin de la colonia. Azángaro 1818”, en Historias, México, en prensa. 
Sin comando único la participación de los indios en la rebelión fue marginada del discurso posterior que canonizó la lucha independentista. En parte por temor a la siempre latente guerra de castas. Pero ellos salieron constantemente a la palestra de la lucha, en acciones dispersas, sin coordinación central, jerarquizadas internamente, cruzadas por relaciones locales de poder y de identificación. El liderazgo que se impuso sobre ellas las incluyó en movilizaciones colectivas de mayor envergadura. $^{8}$

La pregunta certera que Van Young propone es "por qué la gente hace las cosas que hace", y se responde que las hace "por razones muy distintas a las que necesariamente se esperaría por los resultados de sus acciones". Es decir, en el caso de México, estas alteraciones populares tienen una dinámica que nos explica cómo no se trataba de que la Independencia sucediera porque la gente así lo quería. Tal vez, sigue nuestro autor, algunos lo pensaban y deseaban así. ${ }^{9}$

Entre los muchos temas que le discute Alan Knight a Eric Van Young hay uno que puede orientar el comentario que queremos hacer sobre la participación popular en las independencias, un tema que ha sido muy debatido y comentado, tanto en las historias nacionalistas como en las versiones críticas y en las nuevas aproximaciones historiográficas.

Como lo ha señalado más concisamente en uno de sus numerosos artículos precedentes a The Other Rebellion, Van Young afirma que hubo dos rebeliones, la de la élite y la de los campesinos, que miraban hacia atrás, que defendían sus comunidades e identidades. ${ }^{10}$ La comparación que insinúa con los Andes, aquí y en el libro y en otros ensayos, no es con el periodo 1810-1824, sino con los levantamientos de 1780, cuyas posibles relaciones comentaremos más adelante. En el mismo libro colectivo Knight procede a una buena presentación de las corrientes "primordialistas" e "instrumentalistas" en la interpretación de los surgimientos de los

8 Van Young: The Other..., pág. 138.

9 Van Young, Eric: "El Lázaro de Cuautla. Dobles subjetivos al leer textos sobre la acción popular colectiva", en Historia y Grafía, 5, 1995, págs. 165-193. Publicado originalmente en Colonial Latin American Review, vol. 2, núms. 1-2,1993, págs. 2-26. Uno de los temas que retoma en su libro The Other Rebellion.

10 Van Young, Eric: "Los sectores populares en el movimiento mexicano de independencia, 1810-1821: una perspectiva comparada"; Ortiz Mesa, Luis Javier y Víctor Manuel Uribe Urán editores académicos: Naciones, gentes y territorios: ensayos de historia e historiografía comparada de América Latina y el Caribe, XXXIV, Universidad de Antioquia, Medellín, 2000, págs. 141-174, pág. 449. 
estados nacionales. El patriotismo precede al estado nación y fue creciendo paulatinamente entre las élites según Knight, siguiendo a David Brading y otros, apoyado por la idea de Van Young de que no hubo patriotismo entre los campesinos sino campanillismo, a saber, la lealtad al pueblo precede al patriotismo; mientras que Virginia Guedea apuntala una difusión mayor del patriotismo entre la plebe por lo menos en la ciudad de México. Así Eric Van Young es la base de la afirmación de la carencia de inclusión del campesino en la lucha independentista. ${ }^{11}$

Sobre la contradicción en el comportamiento popular frente al rey y los españoles, esta larga trascripción del texto de Knight nos da una idea del tipo de lectura acuciosa que hizo como el calibre de la crítica metodológica que tiene: "El fenómeno de la "escisión" (splitting) se utiliza de manera insistente - y no como un simple comentario- para explicar la aparente contradicción entre la reverencia de los insurgentes hacia Fernando VII y su disposición a matar gachupines. ${ }^{12}$ Me parece que esto es una solución inútil a un problema inexistente - - , por lo menos, un problema inflado al punto de requerir una solución psicoanalítica espuria. Los acontecimientos se explican, en parte, haciendo referencia al "carácter psicológicamente regresivo de las multitudes"13 (psychologically regressive nature of crowds) y a la "dinámica poco menos que universal de las multitudes pequeñas y medianas" (well-nigh universal dynamics of small to medium-sized crowds, $).{ }^{14}$ El padre Correa está, quizás "compuesto [. . .] de personalidades puramente situacionales encajadas una dentro de otra" (constructed [...] of nested purely situational personalities) ${ }^{15} \mathrm{y}$ el clero secular "parecía tener un entendimiento intuitivo" de cómo lidiar con las comunidades insurgentes, tal vez por "alguna memoria racial del aplacamiento de revueltas en los pueblos durante varios siglos" (seemed to have

11 Knight, Alan: "Pueblo, política y nación, siglos XIX y XX", en Ortiz Mesa y Uribe Urán: Naciones, gentes..., págs. 370-406, pág. 392. La referencia de Brading, David: Los orígenes del nacionalismo mexicano. , Ediciones Era, México, pág. 142. Guedea, Virginia: "El pueblo y la política capitalina 1808-1812", Estudios Mexicanos, 10 (1), 1994, págs. 27-61. Se detiene en la aparición del pueblo como actor cuando antes sólo desempeñó un papel secundario en la historiografía. Por entonces, el artículo citado de Van Young, Eric: "Quetzalcóatl, King Ferdinand and Ignacio Allende go to the seashore; or messianism and mystical kingship in Mexico, 1800-1821”, en Rodríguez O., Jaime (ed.): The Independence of Mexico and the Creation of the New Nation, University of California Press, Los Ángeles, 1989, págs. 109-127.

12 Knight: "Eric Van Young: The Other...”, págs. 380-381,471-475 y 637, n. 64.

13 Ibídem, pág. 357.

14 Ibídem, pág. 408.

15 Ibídem, pág. 288. 
an intuitive understanding [. . . ] sorne racial memory of placating village rioters over several centuries)". ${ }^{16}$

Más allá de lo detenido de la crítica, que vale la pena también presentar en esta nota, el tema de esta aparente contradicción —o problema inexistente como quiere Knigth - y la manera como lo soluciona Van Young tiene una raigambre más extensa de lo pensado y, lo que es más, la tendrá todavía en el futuro.

\section{Historiografía}

En un trabajo de envergadura e interés, Marco Antonio Landavazo se propuso "desenmascarar" la visión estereotipada de las ideas políticas de la emancipación como meras formas de velamiento de la verdadera intención o instrumentalización de la figura del rey para legitimar el alzamiento. ${ }^{17}$ Es lo mismo que la historiografía liberal boliviana hizo con Murillo y con los rebeldes paceños. Los estudios bolivianos se han encargado de conferir un carácter de "velada hipocresía" al grito de "viva el Rey" que enarbolaron los actores populares. ${ }^{18} \mathrm{La}$ "guerra contra el Rey con el mismo Rey" ha dicho Estanislao Just, y lo ha seguido Javier Mendoza más polémico y reciente. ${ }^{19}$ Pero, no obstante el esfuerzo por darle "gloria a los hijos de mayo", a los dirigentes, a los doctores del silogismo revolucionario, ${ }^{20}$ a la astucia de Murillo, han dejado incólume el convencimiento de que los alzados del pueblo, los que se agitaron, apedrearon, conmovieron las ciudades, se dejaron llevar por la idea de defender los derechos del Rey. En otro análisis Gunnar Mendoza considera ese "fernandismo" — como lo llama

16 Ibídem. págs. 232 y 462.

17 Landavazo, Marco Antonio: La máscara de Fernando VII. Discurso e imaginario monárquicos en una época de crisis. Nueva España, 1808-1822, El Colegio de México, Universidad Michoacana de San Nicolás de Hidalgo, El Colegio de Michoacán, México, 2001, pág. 357. Difundió su trabajo también en: Landavazo, Marco Antonio: "La sacralización del Rey: Fernando VII, la insurgencia novohispana y el derecho divino de los reyes", Revista de Indias, 61:221, enero/abril 2001, págs. 67-90.

18 Abecia Baldivieso, Valentín: La genial hipocresía de don Pedro Domingo Murillo, Ed. Novedades, La Paz, 1966, pág. 108. Con rigor documental, el autor explica la llamada traición de Murillo como una maniobra política.

19 Just Leó, Estanislao: Comienzo de la Independencia en el Alto Perú. Los sucesos de Chuquisaca, Editorial Judicial, Sucre, 1994, pág. 162; Mendoza Pizarro, Javier: La mesa coja. Historia de la proclama de la Junta Tuitiva del 16 de julio de 1809, PIEB, La Paz-Sucre, 1997, pág. 10.

20 René-Moreno, Gabriel: Mariano Alejo Álvarez y el silogismo altoperuano de 1808, Publicación del Consejo Nacional de Educación Superior, La Paz, 1973. 
Landavazo - un "libreto" de distracción. ${ }^{21}$ Ejemplos similares encontraremos en casi toda la historiografía latinoamericanista. ${ }^{22}$

En México el asunto también partió desde el siglo XIX con la formación de una historiografía nacional, pero se ha consagrado y repetido sin cansancio hasta la actualidad. Para Landavazo se trata de una genuina forma de creencia popular en el rey y un fidelismo especialmente fuerte hacia Fernando VII, que se manifestó antes de la crisis la explosión de la fidelidad- durante ella —explora la ideología y mentalidad subyacentes en las expresiones públicas de lealtad, tanto insurgentes como realistas- y luego del fracaso de la guerra hasta la emancipación —apogeo y decadencia del imaginario monárquico - aunque la figura real, luego de la vuelta al trono de Fernando en 1814, sufrió una erosión. Su punto es que no se trata del ideario sino de las creencias y mitos que informan el comportamiento político. Hace una visión panorámica y no regional y se basa en los escritos, muchos sermones e impresos varios, que son un discurso de letrados o de "elite", pero piensa que se trasvasó al pueblo llano, reconoce empero que no ha hecho un estudio directo de la opinión o sentimiento popular.

El autor había adelantado sus planteamientos en un evento de 1999. Ya entonces mencionaba el trabajo de Van Young y negaba que la figura del rey fuera una imagen mesiánica o milenaria junto a los líderes insurgentes, más bien era un cálculo político que consideraba que frente a la posible derrota española y la traición de los peninsulares, Fernando VII podía instalar su trono en América. ${ }^{23}$

El tema de la figura del rey en relación con el comportamiento político de los indios — no sólo encabezando los alzamientos populares- no pasó inadvertida a otra experta en la época, Virginia Guedea, que estudió el

21 Gunnar Mendoza (transcr.): Causa criminal contra Francisco Ríos el Quitacapas. Años 1809-1811. Documentos para la historia de la independencia de Bolivia, Universidad Mayor de San Francisco Xavier de Chuquisaca, Sucre, 1963.

22 Rodríguez, Jaime: La independencia de la América española, Fondo de Cultura Económica, El Colegio de México, México, 1996, pág. 132 y ss. "La guerra civil en América" señala cómo todos los historiadores han considerado en las más diversas latitudes que los movimientos que se desarrollaron en nombre del rey fueron una pantalla de la meta verdadera que era la independencia. Es el argumento de la "máscara". Pero la fuerza de la evidencia, las invitaciones incluso a gobernar que se le hicieron al rey Fernando muestran lo contrario.

23 Landavazo, M. A: "Fernando VII y la insurgencia mexicana: entre la máscara y el mito", en Terán, Marta y José Antonio Serrano Ortega (eds.): Las guerras de independencia en la América Española, El Colegio de Michoacán Universidad Michoacana de San Nicolás de Hidalgo, Michoacán, 2002, págs. 79-98, pág. 90 . 
comportamiento de los indios de San Juan en México, quienes mostraban su deseo de servir al rey - aunque sus ofertas fueran desatendidas por algunos oficiales reales - a la vez que lo hacían con varios de los grupos insurgentes. ${ }^{24}$ Van Young no está de acuerdo con la posibilidad sugerida por Guedea de que los indios sólo llamasen gachupín a los españoles que residían en México, no a todos los españoles europeos, lo que posibilitaría que la contradicción de matar gachupines a la vez que vivar al rey se explicara porque, justamente, éste no era "gachupín". ${ }^{25}$

Van Young no llega a considerar el trabajo de Landavazo, ni lo mencionan posteriormente los polemistas de Historia Mexicana, cuando este libro ya estaba en circulación. Cierto que uno, Landavazo, es explícito en cuanto a su interés por las expresiones "letradas" que informaban a "todos" - en la medida que lo que la élite escribía provenía de lo que se comentaba y porque se leía en público- pero no daba cuenta directa de lo que el pueblo sentía; mientras que el otro, Van Young, plantea justamente lo contrario. Hubiese sido bueno saber lo que le suscitaba "La máscara..." a Eric Van Young, visto que, sin entrar en el terreno de los debates culturalistas, Landavazo descarta la visión mesianista del regalismo popular. La limitación, si cabe, del estudio de Landavazo ha sido notada en una amplia reseña del libro que hace Alfredo Ávila, que señala la necesidad de estudiar los "discursos subalternos" para llegar a las creencias del pueblo llano como lo hace precisamente Van Young, que no contradice, sin embargo, la afirmación general de Landavazo pero diferencia los discursos de las élites y los populares. La crítica fundamental de Ávila es que no cuestiona el contenido de sus fuentes, a las que concede toda autoridad, sobrevalora las credenciales regalistas que proclamaban muchos con el claro propósito de salvar la vida en muchos casos. ${ }^{26}$ En este rubro, justamente, el trabajo depurado de Van Young al enfrentar los testimonios y los documentos, usando las herramientas más variadas, incluidas las del psicoanálisis, es uno de sus puntos a la vez más interesantes y polémicos, como se ve por la dedicación que le ha merecido a un especialista erudito como Knight.

Mientras escribía esta nota descubrí que la idea de comparar o juntar The Other Rebellion con La máscara de Fernando VII ya la había tenido

24 Guedea, Virginia: "Los indios voluntarios de Fernando VII", en Estudios de Historia Moderna y Contemporánea 10, México, 1986, págs. 11-81.

25 Van Young: The Other..., pág. 472. 198.

26 Ávila, Alfredo: "Reseña”, Estudios de Historia Novohispana, 26, 2002, págs. 196-207, pág. 
el autor de una larga nota que reseña ambas obras. ${ }^{27}$ La manera de representar el asunto por parte de este crítico es muy interesante también. Hay algunos pasajes que no me parecen certeros ni pertinentes como atribuir en Van Young una continuidad — si bien con nueva perspectiva - con las tradiciones conservadoras como la de Lucas Alamán, para quien las acciones populares fueron producto del odio y la revancha independientemente de las de los insurgentes criollos. ${ }^{28}$ Pero más allá de esto, propone con perspicacia una ubicación a ambas obras en el panorama historiográfico mexicano y deja remarcado su aporte personal en un trabajo referido a los pobladores de Uruapan, cuyo tumulto generó un caso de "poder popular" que expulsó a los peninsulares hacia 1767.. ${ }^{29}$ Su punto es que hubo entre los indios y la plebe un sentimiento de identidad que incluía a los "españoles americanos" que se enfrentaba a los "españoles europeos", una conciencia "protonacional".

Si acentuamos algunas críticas y "desenmascaramos" algunos argumentos, quedaría claro que los extremos se juntan. Una panorámica cuyos polos van desde la visión patriótica de la participación épica del pueblo dentro del frente común liderado por los criollos por emancipar la patria común y formar una nación, hasta ésta donde los pobladores rurales, los indios y pobres mayoritarios del "pueblo" mexicano, si bien participan violentamente en la insurgencia, eran ajenos a las ideas de nación o a alguna representación discursiva colectiva; se movían defensivamente, mirando hacia atrás, para rescatar su identidad y su ser colectivo, moral, social y político, tenían "otra rebelión" y, a la postre, la independencia les era ajena. Con todo, al terminar su artículo, el mismo crítico, para reflexionar sobre la posibilidad de una corriente popular a la dominación colonial y del rey que diera pistas a la transición hacia una conciencia nacional dentro del pueblo mismo, apela a las "numerosas referencias y alusiones" que el mismo Van Young proporciona para pensar en una corriente subterránea que cuestionara la legitimidad de la conquista y la hegemonía colonial.

Pero aunque aquella separación de intereses y de representaciones fuese posible, cargando las tintas la conclusión que se saque, la perspecti-

27 Castro Gutiérrez, Felipe: "El imaginario de la violencia popular durante la revolución de independencia”, en Estudios Mexicanos 19:1, 2003, págs. 187-202.

28 Es curioso que Knigth haga su ironía final aludiendo al mismo Alamán, aunque no menciona la nota de Castro Gutiérrez.

29 Castro Gutiérrez, Felipe: Nueva ley y nuevo rey. Reformas borbónicas y rebelión popular en la Nueva España, UNAM, El Colegio de Michoacán, Zamora, 1996. 
va es más rica de lo que esta visión arroja. Tan rica que muchas veces se pierde la ruta, no hay un gran relato y se usa y abusa según la crítica de Knight tanto de palabras como de conceptos. Así, por una o por otra, de tanta atención que merece, el libro se gana fuego graneado.

En cuanto a Landavazo y el tema metodológico que más ayuda a plantearse, cabe notar que el argumento de que los sectores populares quedaban al margen de la cultura letrada sigue siendo un tópico que ignora lo que al respecto ha avanzado la historiografía acerca de la lectura y el vínculo entre cultura escrita y oral en muy distintos espacios y tiempos en la historia previa a la modernidad. También Castro Gutiérrez, como a su turno Alfredo Ávila, señala de Landavazo que al basarse en folletos, sermones y materiales literarios, no podemos saber "hasta qué punto las ideas analizadas recogían las creencias y sentimientos del pueblo o de la masa de los insurgentes". Pero lo más curioso es que el propio autor lo quiere así y para eso incluye lo de que estos escritos representaban opiniones que "flotaban" en el ambiente.

La historia cultural y de la lectura han desarrollado los mejores aportes al respecto del tema que nos ocupa ${ }^{30}$ Los clásicos historiadores de la lectura privilegiaron erróneamente el estudio de los niveles de alfabetización, por lo que partieron de la desigual presencia de libros en los distintos medios sociales, y contabilizaron y registraron minuciosamente los inventarios de las bibliotecas privadas. ${ }^{31}$ Los estudios clásicos contribuyeron a divorciar la lectura de la escritura.

Desde el poder y el gobierno se procuró que la gente aprendiera a leer para evangelizar y someter a través de catecismos y obras piadosas. Este movimiento de ida tuvo una respuesta táctica de vuelta desde la base, a escribir aprendieron las comunidades o individuos que «veían en la escritura un instrumento que permitía una gestión más eficaz de la economía doméstica y la promesa de ascenso social». La ideología dominante procu-

30 Retomo en este punto algunas partes de mi artículo introductorio al número monográfico que coordiné de la revista Debate y Perspectivas. Glave, Luis Miguel: "Del pliego al periódico. Prensa, espacios públicos y construcción nacional en Iberoamérica", en Debate y perspectivas. Cuadernos de Historia y Ciencias Sociales núm. ${ }^{\circ}$, Madrid, 2003, págs. 7-30.

31 Chartier, Roger: "Leer en el siglo de oro", en Revista de Libros 57, Madrid, setiembre de 2001, págs. 31-32, comentario al libro de Bouza, Fernando: Comunicación, conocimiento y memoria en la España de los siglos XVI y XVII, Seminario de estudios Medievales y Renacentistas, Salamanca, 2001. Del mismo autor: "Los porqués de la lectura", Revista de Libros 26, Madrid, febrero de 1999. págs. 37-38, sobre el libro de Cavallo y Chartier: Historia de la lectura en el mundo occidental, Taurus, Madrid, 1998. 
raba que los bajos, mujeres y pueblo, sólo aprendieran a leer. Pero, penosa y laboriosamente, se apropiaron de la escritura, como lo muestran los «papeles» que aparecen en los inventarios notariales o conservados en los archivos. La práctica de la escritura en los medios populares, como muestran claramente los documentos de los archivos americanos, que se expurgan para desentrañar los movimientos culturales que aparecen en la revolución de la independencia, fue mucho más difundida de lo que se había pensado. ${ }^{32}$ Escribir fue romper una barrera, apropiarse de un terreno vedado, desafiar al poder establecido. Por eso no nos debería extrañar que floreciera la escritura y la cultura gráfica en momentos de desafío, de cambio, mientras se mostraban agazapadas y latentes en la práctica cotidiana de la resistencia a las formas de poder y sometimiento. Aun los que no sabían leer tenían acceso al mundo de la cultura escrita.

La génesis de la comunicación nos muestra cómo lo escrito es proyectado con virtudes taumatúrgicas en el seno de una sociedad casi analfabeta, de allí la importancia de la escritura expuesta, pública, en los muros de las ciudades. Hubo distintos soportes que mantenían un alto grado de familiaridad con la escritura de los no letrados: graffitis, lectura en voz alta (escenas de El Quijote lo refieren) y nuevos mercados y públicos para los textos impresos. Los pliegos sueltos que vendían los buhoneros "difundían en las capas más humildes de la sociedad romances, coplas, relaciones de sucesos y comedias". ${ }^{33}$ La conclusión es que la cultura de la modernidad alta fue una «civilización de impronta escrita» donde el gobierno se basaba en la escritura, y la cultura del pueblo estaba en estrecho contacto con la circulación de textos impresos baratos y compartidos.

Como ha señalado Fernando Bouza, con las conquistas de la producción impresa no desapareció el manuscrito y sus múltiples usos: «libelos, sátiras políticas, obras poéticas reunidas en misceláneas, o los textos heterodoxos» se difundían manuscritos, corrían manuscritos como dice uno de sus libros. ${ }^{34}$ Estos manuscritos tenían el carácter de "almacenes donde se

32 Movimientos de información que tomaban ora la forma de rumores, ora la práctica del pasquín o finalmente, la impresión de periódicos que concretaban la propaganda subversiva que los documentos de la época llamaban seductiva. Glave, Luis Miguel: "Una perspectiva histórico cultural de la revolución del Cuzco en 1814”, Revista de las Américas. Historia y presente, núm. 1, Valencia, 2003, págs. 11-38.

33 Castillo, Antonio (comp.): Escribir y leer en el siglo de Cervantes, Gedisa, Barcelona, 1999. Un útil comentario a este libro por Rodríguez de la Flor, Fernando: "La Escritofilia", Revista de Libros $57 . . .$, págs. $32-33$. Madrid, 2001

34 Bouza, Fernando: Corre manuscrito: una historia cultural del Siglo de Oro, Marcial Pons, 
conservaba la memoria escrita de las lecturas de los lectores letrados que hacían escolios manuscritos junto al texto impreso, confeccionaban cuadernos o cartapacios de citas y elaboraban pequeños resúmenes del contenido de los libros leídos", como se puede ver en los archivos andinos y en las prácticas orales perdurables, como el típico recitador y sentenciador. ${ }^{35}$

Otro nivel de integración viene con lo oral. Si lo impreso no desapareció lo manuscrito sino que se intercalaron y retroalimentaron, tampoco la cultura escrita terminó con la oralidad. Son pues tres partes de la comunicación del discurso o mutaciones del mismo que circulaba alternativo entre rumores, pinturas e impresos o que se plasmaba en prácticas que juntaban las tres instancias comunicativas como la predicación o en objetos que lo hacían como los emblemas. Se produjeron, pues, "hibridaciones culturales". Lo escrito mantuvo lo oral y lo plástico.

Por su parte, un estudio de Pedro M. Cátedra nos acerca a la llamada literatura de cordel y su circulación en la península ibérica; antecedente de las relaciones de sucesos que fueron a su vez la antesala del periodismo. Se dedicaban a coplar y recitar sucesos fantásticos con alguna moralina. Su éxito era muy grande. Como señala Bouza, esta obra de Cátedra nos permite señalar que: "Frente al lugar común que supone una radical división entre lo letrado y lo popular en función del grado de alfabetización, Cátedra demuestra la existencia de un fluido circuito que ponía en relación a los lectores cultos con los iletrados, insistiendo en los usos de los pliegos en medios urbanos todavía con aspiraciones de reforma religiosa o, tantas veces, simplemente ávidos de nuevas más sabrosas cuanto más increíbles. Bien como autores, bien como vendedores o recitadores itinerantes, se reconoce el protagonismo que en ese circuito habría correspondido a los ciegos, interesados a título personal o colectivo en superar mediante la composición, venta o recitación de oraciones y coplas el estatus de mendigos dentro de la polémica quinientista sobre la pobreza fingida y las formas de caridad". ${ }^{36}$

35 La Ilustración trajo consigo un mito que negaba las formas de su antecedente y de su gestación: "el mito iluminista, encarnado en la imprenta como culminación de la civilización, llevaba aparejado un rasgo más oscuro, una suerte de dampnatio memoriae de lo anterior, como si su revolucionaria eficacia pudiera ser empañada por las formas de comunicación orales o visuales que la tipografía venía más que a suceder a desterrar" Bouza, Fernando: "Escrituras recobradas", $A B C$ Cultural, Madrid, 25 de mayo de 2002 .

36 Cátedra, Pedro M.: Invención, difusión y recepción de la literatura popular impresa (siglo XVI), Editora Regional de Extremadura, Mérida, 2002. Comentario de Bouza, Fernando: "Ciegos y pliegos", Babelia, Madrid, 7 de septiembre de 2002. 
Es conocido que los pliegos sueltos contaban historias fantásticas, capaces de atraer la atención de un público rústico y de entendimiento ligero. Esa fascinación popular, que llevó a menospreciar el «género» por la historización literaria «nacional», era en realidad su fuerza y su nexo con el mundo mental de esas poblaciones. Entre otros, los estudios mencionados de Pedro M. Cátedra para el siglo XVI y los de Jean-François Botrel en el XIX y $X^{37}$ se han encargado de relacionar lo popular y lo culto, la retórica menor y la mayor, decantando la misma noción de cultura.

Cultura popular o cultura letrada es una disyuntiva epidérmica a la cultura. Lo popular estaba tan ligado a la atmósfera de ideas y sentimientos que trascendían a toda la sociedad, que muchas de ellas eran más populares que aristocráticas o, si se quiere, letradas. La entidad que adquiere en un análisis detenido el paso de ideas a través de los sermones, que se imprimían y convertían en libros o folletos, se pierde al quedar presentada como una excusa o cortapisa al posible talón de Aquiles de no llegar a la "cultura popular", como aparece en el libro de Landavazo. Como señala Castro Gutiérrez, "La máscara de Fernando VII no abunda en las formas de socialización de la cultura política y no se adentra en los complejos relieves y matices de vinculación entre los conflictos sociales y representaciones mentales, entre significantes y significados". ${ }^{38}$ Tal vez, si lo hubiese hecho como en el caso de The Other Rebellion donde se practica con puntillosidad permanente, el argumento defensivo de Landavazo se hubiese trocado en su vanguardia expositiva.

La actitud ante el rey y la violencia contra los "españoles" forman parte de la acción política de los pobladores del campo y de la plebe urbana. Por su parte, Christom Archer ha desarrollado una visión similar a la de aquellos que postulan que los sectores populares hicieron algo más que ser comparsa de un pleito que no les concernía, en un proceso largo y complejo, que incluyó hostigamientos constantes de guerrilla; los indios de las comarcas mexicanas dieron por finalizado el sistema de poder y gobierno que estaba descalabrándose después de la insurgencia de $1810 .{ }^{39}$ Archer trabajó en estudios regionales, sobre el bandolerismo y el ejército hasta

37 Borrel, Jean-François: Libros, prensa y lectura en la España del siglo XIX, Fundación Germán Sánchez Ruipérez, Madrid, 1993.

38 Castro Gutiérrez: Nueva ley...pág. 198.

39 Archer, Christom: Fighting for Small Worlds", en McFarlane, Anthony y Marienne Wiesebron (coord.): Violencia social y conflicto civil: América latina siglo XVIII-XIX, Cuadernos de historia latinoamericana (AHILA), 6, Asociación de Historiadores Latinoamericanistas Europeos: AHILA, Holanda, 1998, págs. 63-92. 
hacer balances generales que, aunque incorporan los aspectos socio económicos, no pueden ser considerados como estudios economicistas o lo que Van Young llama estructuralista o materialista, como acertadamente señala Knight para el trabajo de Hamnett. Archer forma parte de la renovación de la historia mexicana que tiene un elenco que incluye a Jaime Rodríguez, ${ }^{40}$ Peter Guardino, ${ }^{41}$ John Tutino ${ }^{42}$ y William Taylor ${ }^{43}$ a quienes Knight suma a Nancy Farris ${ }^{44}$ dentro de las posibles polémicas que encuentra entre los planteamientos de Van Young y los de estos autores.

El estudio de los casos de tumultos, lo mismo que las "bullas" y "tole toles" que analiza Nuria Sala en los Andes, ${ }^{45}$ es un argumento central en el libro de Van Young. Como bien han señalado tanto Knight como Castro Gutiérrez en sus críticas, es lo contrario al planteamiento de Tutino que las descartó en su estudio de la subversión en los valles centrales. Van Young usa estas conmociones locales desvinculadas de la insurgencia general, desde tiempo anterior a ella y que se prolongan durante ésta, como una característica de la otra rebelión, la popular que, sin ser un movimiento colectivo, forma una acumulación a escala mayor de los casos de violencia local. El trabajo de Van Young se vincula así, según Castro Gutiérrez con el clásico de William Taylor. ${ }^{46}$ Ambos muestran lo que en alguna corriente de interpretación histo-

40 Rodríguez, Jaime: La independencia de la América española, Fideicomiso de historia de las Américas, El Colegio de México, FCE, México, 1996. Supone Knigt que Rodríguez postula el vínculo con la crisis hispana mientras Van Young enfatiza lo interno además en una perspectiva de continuidad.

41 Guardino, Meter: Campesinos y política en la formación del estado nacional mexicano. Guerrero, 1800-1857, Chilpancingo, Gobierno del Estado libre y soberano de Guerrero, 2001. Es el trabajo que contrapone como ejemplo de postulado de participación popular en la emancipación frente a la visión "divergente" de dos rebeliones que postula The Other...

42 Tutino, John: De la insurrección a la revolución en México: las bases sociales de la violencia agraria, 1750-1940, Era, México, 1990. La primera parte trata de los orígenes de la insurrección de Hidalgo en 1810 y las reacciones y proyecciones que tuvo.

43 Taylor, William B.: Ministros de lo sagrado: sacerdotes y feligreses en el México del siglo XVIII, El Colegio de México, Secretaría de Gobernación, El Colegio de Michoacán, 1999. 2 v. Particularmente el capítulo de conclusión dedicado a los curas párrocos y la insurrección y a la teología moral de José María Morelos, págs. 665-708. Otro trabajo mayor con el que suélese comparar The Other Rebellion sobre todo por la contemporaneidad de la publicación de ambos.

44 Farris, Nancy M.: La corona y el clero en el México colonial: 1579-1821. La crisis del privilegio eclesiástico, Fondo de Cultura Económica, México, 1995. Tiene un capítulo dedicado a la inmunidad eclesiástica durante la independencia (págs. 183-218) y su conclusión se titula "La independencia: el triunfo de la reacción”, pág. 219. Incluye un apéndice con los participantes eclesiásticos en el movimiento hacia la independencia. Knight contrapone las hipótesis de Van Young sobre los curas con lo que postuló este libro.

45 Sala i Vila, Nuria: Y se armó el tole tole. Tributo indígena y movimientos sociales en el virreinato del Perú 1784-1814, Instituto de Estudios Rurales José María Arguedas, Ayacucho, 1996.

46 Taylor, William: Embriaguez, homicidio y rebelión en las poblaciones coloniales mexicanas, Fondo de Cultura Económica, México, 1987. 
riográfica se llaman las "resistencias adaptativas", también lo que Thompson llamaba la "economía moral", forma de analizar los movimientos sociales que tuvo mucho predicamento tanto en México como en los Andes. ${ }^{47}$

El propio Tutino en un artículo más reciente hace una sumilla de su hipótesis: "la insurgencia empezó como una incierta alianza entre criollos, que buscaban una participación política, y los dependientes de las haciendas que exigían una mejor distribución de los recursos agrarios". ${ }^{48}$ Luego se centra en la zona que estudió posteriormente a su libro clásico, el Mezquital: "Miles de insurgentes otomíes se sumaron al conflicto por cuatro o cinco años en pos de visiones de una independencia agraria" "operaron como aliados - mas no seguidores- de los líderes más bien hispánicos y políticos como Julián Villagrán” y pelearon mucho tiempo más después de la derrota de éste. Nunca fueron derrotados y si se desmovilizaron, fue por acuerdos que los dejaron en control de sus comunidades. No ganaron pero tampoco fueron derrotados y tenían "sus propias visiones de independencia" ${ }^{49}$ y lograron algo de autonomía y avances respecto de sus propios fines. Aunque eran otomíes, sus historias y la diferencia del medio geográfico los hicieron actuar de distintos modos. En el Bajío los otomíes no se sublevaron como los mestizos, y en el Mezquital los indios fueron los rebeldes. La insurgencia en la zona difiere de la del Bajío: está contra los curas, los expulsa y tiene una visión de la independencia que requería acabar con la autoridad clerical.

A Tutino le interesan los procesos internos, los cambios y heterogeneidades de los grupos que conforman las sociedades rurales. Concluye que tanto en el Bajío como en el Mezquital entre 1810 y 1820 "se movilizaron diversas comunidades populares en búsqueda de visiones de independencia locales y a menudo profundamente agrarias". La independencia como toma y centralización del Estado les era contraria a sus afanes de independencia local. Fueron insurgencias regionales que adelantaron las luchas por el federalismo del siglo XIX. Continuaron sus luchas por la autonomía comunita-

47 Ver por ejemplo Stavig, Ward: "Ethnic conflict, moral economy, and population in rural Cuzco on the Eve of the Thupa Amaro II rebellion”, Hispanic American Historical Review 68:4, 1988, págs. 737-770; Larson, Brooke: Colonialism and agrarian transformation in Bolivia: Cochabamba,1550-1900, Princeton University Press, Princeton, 1988; el mismo estudio introductorio de Stern, Steve: Resistencia, rebelión y conciencia campesina en los Andes, siglos XVIII-XX, Instituto de Estudios Peruanos, Lima, 1990.

48 Tutino, John: "Buscando independencias populares: conflicto social e insurgencia agraria en el Mezquital mexicano, 1800-1815”, en Terán, Marta y José Antonio Serrano (eds.): Las guerras de la independencia..., págs. 295-321, pág. 295.

49 Tutino: "Buscando independencias populares...", pág. 318. 
ria hasta la revolución mexicana. Pero, y en esto estriba la diferente visión del proceso respecto de Van Young, piensa que es "absurdo excluir estas movilizaciones populares que pelearon la autonomía provincial y local de la categoría de los movimientos independentistas". ${ }^{50}$ Eso ocurrió por la forma como se divulgó luego y se recepcionó la historia de la emancipación. En las visiones de la independencia, los nacionalistas centralistas deslegitimaron a los localistas y regionalistas, crearon un concepto de independencia que coincidía con su interés centralizador, usurparon el lenguaje y negaron la participación popular en los conflictos.

El elenco de obras paralelas será incompleto siempre, más en un tema como éste, pero a los que se refiere la aludida crítica de Knight hay que añadir el trabajo pionero y señero de Hamnett ${ }^{51} \mathrm{y}$ dos obras que tienen peculiaridades que conviene puntualizar, la más nueva de Ortiz Escamilla y una ya larga y sólida de Virginia Guedea.

Es un trabajo muy interesante el de Juan Ortiz Escamilla sobre la independencia mexicana. ${ }^{52}$ Empieza con una evaluación de la historiografía de la independencia para llegar a su objetivo de retratar los pueblos de Michoacán, Guanajuato, donde se produjo el grito de Dolores, conocidos como "cuna de la independencia", desde el punto de vista de su propia historia. No hace propiamente una historia desde lo local a lo general como alguno de la historiografía francesa que comentaremos más adelante, pero va en esa dirección, se recrea en los pueblos y en sus circunstancias, sus redes de poder y su ingobernabilidad. Los apéndices dan referencias sobre los pueblos rebeldes, los ataques de uno y otro bando, los jefes, la participación popular, etc. Parte de algunas preguntas muy perspicaces como, por ejemplo, si era necesario hacer una guerra larga y destructiva sólo para establecer una nueva relación con el rey, a lo que responde que no, que los líderes se planteaban la emancipación pero, como en el caso sudamericano, "engañaron" al pueblo, de manera que se pregunta también si esto era necesario y por qué. Se remite a 1808 pero lo que le interesa son los movimientos de 1810 que se ven potenciados ideológicamente por la Constitución de 1812 y cuyo resultado se expresa "por lo menos en el papel" en 1823. Su visión entonces es de un proceso de emancipación. Apunta a la fuerza que adquieren las dinámicas loca-

50 Ibídem, pág. 319.

51 Hamnett, Brian: Roots of Rebellion, Mexican Regions, 1750-1824, Cambridge University Press, Cambridge, 1986. Cito por la edición en español: Raíces de la insurgencia en México: historia regional, 1750-1824, FCE, México, 1990.

52 Ortiz Escamilla, J.: Guerra y gobierno. Los pueblos y la independencia de México, Colección Nueva América, Universidad Internacional de Andalucía y otros, Sevilla, 1997. 
les, la autonomía de sus procesos y de la conciencia que logran tener en la marcha de la guerra, que llevaron a una fuerte tendencia federal que, sin embargo, no terminó haciendo estallar el proyecto de Estado nacional sino todo lo contrario, lo sustentaron desde las localidades. Luego, entre 1830-35 con Santa Anna y más tarde con la invasión norteamericana, se consolidó el Estado central remitiendo las tendencias federalistas.

El trabajo de Virginia Guedea se encamina a los espacios públicos y a las nuevas formas de sociabilidad..$^{53}$ A su libro más conocido suma los artículos que hemos consignado previamente sobre la irrupción del "pueblo" en la revolución y la inclinación por Fernando VII de muchos insurgentes. Ha hecho otras novedosas incursiones en las sociedades secretas como la de Jalapa que fue otro caso, poco exitoso y corto, de sociedad secreta al lado de la mexicana de los guadalupes al que dedicó un libro. La sociedad jalapeña se formó a imagen e instancias de la Sociedad de los Caballeros Racionales de Cádiz que formó el argentino Carlos Alvear con el padre Servando Teresa de Mier, con el objetivo de defender la patria y ayudarse por beneficencia. No eran rupturistas todavía, a la usanza de los discursos de la época y de las interpretaciones aceptadas luego, pero eran corporaciones que fundían compromisos políticos de nuevo tipo. Hubo una sociedad secreta de españoles también, probablemente por temor a las actividades criollas, pero resulta interesante notar que se sospechó que ellos también apoyaban a los insurgentes, probablemente buscando tener buenas relaciones con ellos. El artículo tiene muchas anécdotas y referencias cotidianas muy amenas que no son desechables en el afán de difundir los hallazgos de los historiadores. ${ }^{54}$

La compilación de ensayos aparecidos en Historia Mexicana, en una colección de difusión del Colegio de México, convierte a V. Guedea además en una promotora de debates y una difusora de nuevos temas. ${ }^{55}$ No es una novedad desde luego, pero otra compilación suya reunió propuestas

53 Guedea, Virginia: En busca de un gobierno alterno: los Guadalupes de México, UNAM, México, 1992

54 Guedea, Virginia: "Una nueva forma de organización política: la sociedad secreta de Jalapa, 1812", en Garrita, Amaya (coord.): Un hombre entre Europa y América: homenaje a Juan Antonio Ortega y Medina, UNAM, México, 1993, págs. 185-208. Sobre el mismo tema de las sociedades secretas, que junta este artículo y lo que hace en su libro sobre los Guadalupes, ver su ensayo incluido en el excelente libro de Rodríguez, Jaime E. (ed.): The Independence of Mexico and the Creation of the New Nation. Latin American Studies, UCLA, Los Angeles, 1989. "Las sociedades secretas durante el movimiento de independencia", págs. 45-62.

55 Guedea, Virginia (comp.): La revolución de independencia, Lecturas de Historia Mexicana, El Colegio de México, México, 1995. 
sobre el tema del vínculo con la crisis hispánica. Son ensayos que muestran la vastedad del territorio y los vínculos con Cádiz y con España, un conjunto amplio y complejo de iniciativas, diversas, difícil de tipificar como un todo unificado. Escriben: Chust, Rodríguez, Ortíz Escamilla, H. De Gortari, la propia coordinadora y otros. ${ }^{56}$

La historiografía sobre la transición mexicana a la república tiene ya muchos y flamantes temas, nuevas o recuperadas perspectivas de análisis y renovada periodización. Como lo revelaron las atinadas contribuciones de un libro breve editado por McFarlane y Posada-Carbó. ${ }^{57}$ Entre los autores figuran dos de los especialistas más citados, en diferentes momentos, primero un clásico como Lynch y luego François Xavier Guerra cuyos aportes y magisterio han sido tan amplios como reconocidos. La contribución de Lynch demandaba más atención a la demografía, a la religión y a las ideas, en lo que, sin embargo, visto el panorama previo, no tiene mucha razón. Luego contrapone política a socioeconomía, lo interno a lo imperial y el periodo amplio de 1750-1850 al clásico y restringido de 1810-1825. Pero no son contrarios y el periodo sugerido como mejor por Lynch no es tomado en cuenta por los autores que han vuelto al clásico político (y militar) aunque renovando temas. Guerra plantea el tema culturalmente, al subrayar el gran cambio de conjunto que significó y al plantear que no fueron luchas de emancipación nacional, pues de una misma "nacionalidad" se desenvolvieron diversos estados, la emancipación precedió a las naciones, los nacionalismos y los mismos estados de donde se desarrollaron los anteriores..$^{58}$

56 Guedea, Virginia (coord.): La independencia de México y el proceso autonomista novohispano 1808-1824, UNAM/Instituto Mora, México, 2001. Hay al respecto de este tema una muy útil compilación de Chust, Manuel e Ivana Frasquet (eds.): La Trascendencia del liberalismo Doceañista en España y América, Biblioteca Valenciana, Conselleria de Cultura, Generalitat Valenciana, Valencia, 2004. Edición que no es la única de ese grupo muy dinámico de estudios y debates sobre el tema independentista.

57 McFarlane, Anthony y Enrique Posada-Carbó (eds.): Independence and Revolution in Spanish America: perspective and problems, University of London, Institute of Latin American Studies, Londres, 1999. Hay una larga y perspicaz reseña del libro que revela el interés por la renovación metodológica de Landavazo, en Estudios de Historia Moderna y Contemporánea, 20, 2000, págs. 131-138. En el elenco recopilado está otro autor imprescindibles como T. Anna.

58 Hay una renovada incursión en el tema por el propio Guerra en un artículo póstumo, ver Guerra, Francois-Xavier: "La ruptura originaria: mutaciones, debates y mitos de la Independencia", en Álvarez Cuartero, I. y Sánchez Gómez, J. (eds.) Coloquio Internacional de Historia de América . Visiones y revisiones de la independencia americana, III Coloquio Internacional de Historia de América "La independencia de América"(2001), Ediciones Universidad de Salamanca, Salamanca, 2003; (Aquilafuente, 52), págs. 89-110. 
Dentro de este panorama, en el que ya los nuevos estudios son tantos como el mar de publicaciones que fijaron las bases de la historiografía nacional aquí y allá en América Latina, viene a irrumpir esta The Other Rebellion que logra remover y renovar. Tal vez no sea uno de sus aportes menores el trabajo con las fuentes y la perspectiva. Ya no será posible que las miren incompletas, un pedazo de expediente sin saber del todo. Encima, se toman de los pedazos pedacitos y se citan de oídas, es necesario meterse y arriesgarse en ese mar de datos y dar a cada elemento su peso específico. No es, como vemos, nuestro autor el único, son muchos y muy variados como para puntualizar a qué corriente pertenecen, salvo que se quiera construir "hombres de paja" como señala Van Young. La polémica aquí parece bizantina, lo complejo de determinar lo que sería materialista, estructural, economicista y otros nombres puede ser tan largo, denso y tan (in)útil como el fijar el canon de lo cultural, posmoderno, microhistórico, hermenéutico, historiográfico y más que han venido en sucesivas oleadas a renovar lo que de suyo camina renovando y removiendo como es la historia.

\section{Historia cultural}

Con particular aprecio, Van Young menciona en su debate un artículo suyo donde proclamó su interés por la nueva historia cultural y la influencia que ésta tenía ya en los estudios mexicanistas. ${ }^{59}$ Ya en la concreción del libro esa impronta se hace notar y es a partir de allí de donde vienen algunos de los principales recelos de algunos de sus colegas. Se trata de algo de mucho interés para la historiografía latinoamericana y no sólo un asunto de gustos o modas académicas. Ya hemos ido viendo en las páginas previas cómo hemos tenido que entrar a comentar la presencia de argumentos vencidos por el peso de estudios numerosos y sólidos, de los más variados orígenes y lugares, que siguen siendo ignorados a la hora de plantearse temas culturales como el caso de la lectura. En general, se trata de asumir la verdadera naturaleza de la cultura popular para entender los comportamientos de las mayorías rurales, indígenas y campesinas, de la plebe urbana, de los estamentos de lo que luego sería el pueblo en las sociedades americanas en sus transiciones poscoloniales.

59 Van Young, Eric: "The New Cultural History Comes to Old Mexico", Hispanic American Historical Review 79:2, 1999, págs. 211-247. Es la declaración de sus intenciones sobre estas perspectivas y sus posibilidades. 
Los distintos caminos que llevaron al regreso de la historia narrativa y al auge de lo social sobre lo económico de los años setenta dieron paso a un aglutinamiento de tendencias que confluyeron en el predominio de la historia cultural en los ochenta ${ }^{60}$ Ya había explotado el "giro lingüístico" y se habían manifestado en todos sus extremos los postulados posestructuralistas y también deconstruccionistas. Más allá de lo largo y complicado que parecían sus denominativos, fueron un fermento que acompañó a los revisionismos historiográficos que desembocaron en ese auge cultural que se denominó el "giro cultural" o la "nueva historia cultural". Giro que no sería el último, pues todavía tendríamos el "giro historiográfico". Lo llamativo de este agrupamiento historiográfico por lo cultural es que se trató de una suma y un continuo: llegaba sumando, no cortaba o hacía tabla rasa ni restaba valor a los aportes previos o perspectivas diferentes a sus planteamientos generales - aunque cabe destacar el rechazo genérico que se hizo de los planteamientos más radicales de la teoría literaria - que llevaban a los historiadores a una revitalizada propuesta multidisciplinar. Así, la microhistoria de Ginzburg, Darnton y otros, la cultura popular de Burke y desde luego Bajtin, la antropología de Geertz, la sociología de Elías, la historia de las mentalidades de Duby, el marxismo culturalista de E.P. Thompson, o los aportes historiográficos de White se sumaban en un nuevo paradigma, abierto a múltiples desarrollos. Como lo señala en muchas partes de su trabajo, Van Young trata la producción de símbolos en la historia, una de las tareas que se impone la historia cultural junto con las formas de percepción y las prácticas. Junto con estos, los temas que aparecieron fueron los punteros de la renovación historiográfica: la historia de la vida cotidiana, la antropología histórica, historia de las mujeres e historia de género, historia del discurso, historia de los conceptos y otros. ${ }^{61}$

La cultura fue el ámbito por excelencia del desenvolvimiento de la historia, la sociología se hizo histórica. Cambiaron los temas pero también las formas de afrontarlos. Los relatos microhistóricos, de los que The Other Rebellion está lleno, se desarrollaron a partir de estos planteamientos. Muchos marxistas se inclinaron por la microhistoria, sin embargo, en el debate entre Knight y Van Young, éste rebate la crítica de aquél de inclinar la balanza hacia lo cultural dejando de lado lo económico, al mismo tiem-

60 Aurell, Jaime: "El giro cultural", La escritura de la memoria. De los positivismos a los posmodernismos, Universitat de València, Valencia, 2005, pág. 180.

61 Como resume muy bien Daniel, Ute: Compendio de historia cultural. Teorías, práctica, palabras clave, Alianza, Madrid, 2005, pág. 24. Compendia los debates sobre la historia dentro de esta denominación cultural y señala cómo su tendencia es la apertura hacia las disciplinas vecinas que en conjunto llama ciencias culturales. 
po que acepta y defiende su manera de plantear su entrada al mundo de la violencia popular por calas puntillosas y detenidas, que hurgan en los pliegues más pequeños, incluso de las creencias y psique de los actores.

Lo mismo que con la microhistoria, los estudios de la memoria, la mentalidades colectivas e identidades, que parten del narrativismo revitalizado, como los plantea Paul Ricoeur, incluyendo el "retorno" o rescate de Maurice Halbwachs uno de los fundadores con Durkheim de la escuela sociológica francesa, han sido parte de este movimiento historiográfico hacia lo cultural; ${ }^{62}$ para no hablar del potente planteamiento de la historia de los conceptos de Koselleck en el campo de los historiadores alemanes. ${ }^{63}$ Hay incluso desarrollos muy sugerentes de una historia local que tiene el mismo espíritu globalizador - que parte de lo local— de los microhistoriadores, como los aportes de Maurice Agulhon que es continuador de las líneas francesas de hacer historia, hasta no hace mucho las más comentadas y vitales. No se puede establecer con claridad una línea divisoria entre una y otra forma de hacer historia dentro de los desarrollos que corresponden a un momento que se puede denominar como el de "la nueva historia cultural", pero en cualquier caso, estamos ante una evidente eclosión de formas de hacer historia que debaten vivamente sobre su ser y su estar en nuestras sociedades y en la sociedad global finisecular del XX.

Los planteamientos que informan los microrelatos y la estrategia de presentación de un libro tan vasto como el de Van Young tienen esa impronta y el autor trata de mostrarlo. Van Young recuerda muy acertadamente que no es lo mismo "posmodernismo" que historia cultural, se decanta por la segunda y plantea que recogiendo los aportes que se han hecho dentro de ese magma, quiso aportar con esa perspectiva el estudio de los movimientos sociales y la violencia política. ${ }^{64}$ Lo mismo ocurre con el sello de otra corriente que viene desde otras latitudes y que irrumpe en la historiografía norteamericana como son los estudios subalternos, vinculados a la historia social como bien lo señala Van Young y que provienen de los estudiosos de la India, que en sus influencias latinoamericanistas Knight también critica. ${ }^{65}$

62 Péquignot, Bruno (comp.): "Tiempo, memoria y emoción. Retorno a Maurice Halbwachs", en Historia, antropología y fuentes orales, 32, entre fábula y memoria, Barcelona, 2004, págs. 89-175. Dossier que reúne trabajos de Namer, Fleury y otros.

63 Fernández Sebastián, Javier y Juan Francisco Fuentes (eds.): Dossier "Historia de los conceptos", en Ayer. Revista de historia contemporánea, 53, Madrid, 2004.

64 Van Young: "De aves y estatuas..." pág. 524.

65 Knight, Alan: "Subaltern, Signifiers, and Statistics: perspectives on Mexican Historiography”, en Latin American Research Review, 37, 2002, págs. 136-158. 
Vinculada a una ONG que fomenta los estudios e intercambios "sursur", Silvia Rivera difundió en Bolivia esta perspectiva traduciendo y prologando unos artículos aparecidos en la ya célebre revista Subaltern Studies y ha tenido tal éxito que su libro es casi una obra de culto. ${ }^{66}$ Difusores de los estudios subalternos en América Latina como Zermeño y Dube, en sus reseñas agradecen que les hayan facilitado un ejemplar del libro. ${ }^{67}$ De igual forma que se puede comprobar en muchos programas universitarios de toda la América Latina que lo sugieren como bibliografía en las asignaturas más diversas, desde los estudios de género hasta los literarios pasando desde luego por la historia y la antropología porque como señala Dube salvo esa publicación y el dossier de Zermeño en Historia y Grafía, Latinoamérica estaba hermética a esta influencia que se abrió paso en los Estados Unidos, donde se formaron grupos de estudio y se hicieron algunas publicaciones señeras e intervenciones editoriales muy comentadas como la de Florencia Mallon, cuya obra forma parte de los debates que acompañan el tema que Van Young informa. ${ }^{68}$

En las investigaciones que he venido realizando sobre los movimientos sociales y la revolución en el sur andino a inicios del siglo XIX, pude comprobar lo que afirma Van Young en varios pasajes de su obra: las formas de hacer historia cultural son un punto de llegada y no uno de inicio. Es decir, surgen como necesidad para ahondar en el conocimiento de un tema que ha sido visitado de mil maneras previamente y que sigue tan escurridizo como necesario es darle una interpretación que no sea un dogma o una visión parcial.

\section{El mundo andino}

Terminaremos estas notas historiográficas haciendo algunas comparaciones o alusiones a los procesos que se vivieron en el mundo andino. Como señalamos, los historiadores comprometidos en el estudio del proce-

66 Rivera Cusicanqui, Silvia y Rossana Barragán (eds.): Debates post-coloniales: una introducción a los estudios de la subalternidad, La Paz, 1997.

67 Kraniauskas, John y Zermeño, Guillermo: Expediente "Historia y subalternidad", en Historia y Grafía, 12, México, 1999, págs. 9-178; Dube, Saurabh (coord.): Pasados poscoloniales, , El Colegio de México, México 1999.

68 Mallon, Florencia: Peasants and Nation: the Making of Postcolonial México and Perú, Berkeley University Press, Berkeley, 1994. 
so novohispano han tendido a comparar los temas relativos a la violencia política popular más que con la coyuntura previa a la emancipación con la era de las grandes rebeliones indígenas del siglo XVIII. En ello influyó un libro colectivo publicado por Steve Stern que reunió las más innovadoras visiones sobre ese también impresionante escenario de violencia, convulsión y cambio. ${ }^{69}$

El libro y el programa de la reunión que le dio origen reflejan una concepción más o menos general acerca de la participación rural y popular en cuanto a la era de la emancipación: no hubo tal. Los estudios van desde mediados del siglo XVIII hasta la actualidad, pero, salvo la incursión original y heterodoxa de Flores Galindo en el mundo cultural de los supuestos sediciosos Aguilar y Ubalde en 1805, considerado luego un capítulo de la "lucha por la independencia", no hay ninguna contribución sobre guerrillas, montoneras, tumultos, motines o participación popular en movimientos de más envergadura como la revolución cuzqueña de 1814 o las campañas en la época final de 1821-1824.

Al calce con el tema tratado en el movimiento cultural novohispano, conviene aquí llamar la atención respecto del punto tratado por uno de los contribuyentes al libro comentado. Jan Szeminski pretende mostrar la forma en que tanto Tomás Katari como Túpac Amaru dijeron actuar en nombre del rey que les habría ordenado matar a los españoles. Se había producido en la mentalidad popular un fenómeno de diferenciar a los españoles en el país de una España que supuestamente los apoyaba y defendía. Todos los indios insurgentes del XVIII dijeron actuar en nombre del rey, así lo hicieron también los continuadores de José Gabriel. No explica cómo se produjo, pero que la figura real era buena y de ella emanaba la autoridad de los jefes indios es una evidencia abrumadora. ${ }^{70}$

69 Stern, Steve J. (comp.): Resistencia, rebelión y conciencia campesina en los Andes: Siglos XVIII al XX, Instituto de Estudios Peruanos, Lima, 1990. Conviene advertir el interés que para las comparaciones tuvieron, la introducción del compilador: Stern, Steve: "La era de la insurrección andina, 1742-1782: una reinterpretación”, págs. 50-96, que llama a desarrollar la perspectiva cultural en los estudios del tema y el artículo de Szeminski, Jan: “¿Por qué matar a los españoles? Nuevas perspectivas sobre la ideología andina de la insurrección en el siglo XVIII”, págs. 164-186. Allí apareció el primer artículo (Flores Galindo, Alberto: "Buscando un inca", págs. 187-199) que luego daría lugar al libro de Flores Galindo, Alberto: Buscando un inca: identidad y utopía en los Andes, Instituto de Apoyo Agrario, Lima, 1987.

70 Szeminski, Jan: Los objetivos de los tupamaristas. Las concepciones de los revolucionarios peruanos de los años 1780-1783, Instituto de Historia, Academia Polaca, Wroclaw, 1982, págs. 169170. Se basa largamente en la CDIP. 
Pero otros autores han dado nuevos y significativos pasos en el entendimiento de estos movimientos políticos usando los aportes que entonces se publicaron y nueva investigación de archivo trabajada con otras perspectivas historiográficas. ${ }^{71}$

Así tenemos a Sergio Serulnikov que estudia el norte de Potosí, la provincial de Chayanta y el alzamiento de Tomás Catari, uno de los tres que formaron en 1780 el gran movimiento revolucionario que llama pan-andino y que confluyó en la jefatura unificada de los Túpac Amaru con los quechuas y Túpac Catari con los aymaras. Su punto es que este movimiento informa sobre la cultura política subalterna de los indios, las formas de revitalización de sus tradiciones y el desafío al sistema de poder y autoridad coloniales que llevaban siglos imponiéndose en esa vasta región. Tan imbricado como estuvo el alzamiento de nor-Potosí con la tramoya cultural que significó ese movimiento amplio que surgió del prestigio y la fuerza del discurso de Túpac Amaru, Serulnikov abraza las hipótesis más sugerentes sobre el alzamiento cuzqueño, como las de Alberto Flores Galindo, y las usa para comparar el movimiento tupamarista con los que salieron del ámbito Aymara a los que luego se sumarían. En un momento de su conclusión, llega a plantear que el apelar de Túpac Amaru tanto a indios como a blancos nacidos en los Andes "puede apuntar a una incipiente formación de una discreta 'comunidad imaginada' interracial". ${ }^{2}$

Aquí engarza con otro trabajo que renueva la visión que tenemos de las rebeliones andinas, el de Sinclair Thomsom que analiza la dinámica del movimiento paceño de Túpac Catari y focaliza su atención en la dinámica de la insurgencia popular. Cabe notar que ambos autores, interesados como están en la cultura política de los campesinos e indios, ubican las zonas y los momentos históricos desde el punto de vista de lo social y económico, vinculando los aportes que se han hecho desde hace más tiempo a la renovación del conocimiento de una época tan crucial para la historia andina y

71 Por mi parte, hice un balance de lo publicado y lo relacioné con mi propia investigación en Glave, Luis Miguel: "The "Republic of Indians" in Revolt (c.1680-1790)" en Salomón, Frank and Stuart Schwartz (eds.): The Cambridge History of the Native Peoples of the Americas, Vol. III, South America, Part 2, Cambridge University Press, New York, 1999, págs. 502-557. Desde entonces a esta parte, las novedades son muchas, aunque lo que sostuve allí sigue teniendo validez y sentido para que pueda servir de derrotero.

72 Serulnikov, Sergio: Subverting Colonial Authority. Chalenges to Spanish Rule in Eighteenth Century Southern Andes, Duke University Press, Durham, 2003, pág. 217. Véase también: Serulnikov, Sergio: "Legitimidad política y organización social en las comunidades indígenas de la Chayanta (siglo XVIII), en dossier Charles F. Walker (coord.): Los Andes en el siglo XVIII, Anuario de Estudios Americanos, 61/1, Sevilla, 2004, págs. 69-101. 
americana en general. No tiene que haber una oposición entre economía y cultura. ${ }^{73}$

En un comentario sobre un libro de Juan Pablo Fusi, La patria lejana, firmado por José M. Portillo, me resultó atrayente la crítica que le hace a Fusi que piensa que hubo una escasa socialización política entre las poblaciones indígenas americanas: "la caracterización de la mayor parte de las naciones americanas y sus sociedades resultaría decididamente otra si no se siguiera aún en la estela de la interpretación historiográfica liberal-nacionalista hispanoamericana - y, por tanto, también española— que etiquetó al mundo indígena como inadaptado a la modernidad de las formas políticas. Hay literatura reciente que demuestra que la historia moderna de los pueblos indígenas puede leerse desde perspectiva bien distinta y en la que, por consiguiente, lo primero que surge es justamente una potente socialización política, con su modernidad incluida". Cita como la fuente de inspiración de su acertada idea nada menos que a We Alone Will Rule. Native Andean Politics in the Age of Insurgency.$^{74} \mathrm{El}$ mismo autor, citando el mismo libro, deja claro que la lucha por la autonomía eurocriolla que se dio luego en lo que llama "la crisis Atlántica de 1808" hubiese tenido un buen precedente de referencia en estos movimientos sino los hubiese descartado por "inservibles muestras de barbaridad". ${ }^{75} \mathrm{Y}$ es que tachar de insano, bárbaro, loco, incomprensible, es siempre un mecanismo de marginación, un cerrar los ojos al camino de la verdad. Sorpresa y desconcierto que debieran dejar la gran enseñanza: "cuando no podemos comprender un proverbio, un chiste, un rito o un poema, estamos detrás de la pista de algo importante. Al examinar un documento en sus partes más oscuras, podemos descubrir un extraño sistema de significados. Esta pista nos puede conducir a una visión del mundo extraña y maravillosa". Una cosmología que parece irremediablemente perdida y que para rescatarla, venciendo nuestra incredulidad, la historia cultural no debe "evitar lo raro o preferir lo común" de manera que "apartarse del camino trillado quizá no es una metodología, pero así se tiene la posibilidad de disfrutar de visiones poco usuales, que pueden ser muy reveladoras". ${ }^{76}$

73 Thomsom, Sinclair: We Alone Will Rule. Native Andean Politics in the Age of Insurgency, The University of Wisconsin Press, Madison, 2002 y la reseña de Sergio Serulnikov, en Anuario de Estudios Americanos, LX-2, Sevilla, 2003, págs. 723-726.

74 Comentario de José M. Portillo sobre un libro de Fusi, Juan Pablo: La patria lejana, Revista de Libros de Caja, núm. o 84, Madrid, , pág. 16.

75 Portillo, José M.: "Autonomía y Constitución. La historiografía y la crisis atlántica de 1808" en Istor, Revista de Historia, 162004.

76 Darnton, Robert: La gran matanza de gatos y otros episodios de la historia de la cultura francesa, Fondo de Cultura Económica, México, 1987, págs. 12-15. 
Es interesante notar en el trabajo de Serulnikov que la lucha política parte de una erosión interna en la comunidad y en el de Thomson que es desde la lucha política que se rehacen o recrean las comunidades. Es lo mismo que quise expresar con el título de mi estudio sobre los grupos indios canas y canchis del sur del Cuzco, un proceso étnico de creación y recreación de las comunidades. ${ }^{77}$ En uno de los capítulos, que luego expandí, hago una microhistoria del poblado de Coporaque y su curaca Sinanyuca, donde las filiaciones y actitudes políticas tienen mucho que ver con símbolos y cultura, tanto como con una disputa por recursos. ${ }^{78}$ En ese escenario andino, como lo señala Van Young en México, la gente hace las cosas de manera y "por razones muy distintas a las que necesariamente se esperaría por los resultados de sus acciones".

Por su parte, Ward Stavig tiene un buen número de contribuciones acerca de la región donde estalló la revuelta de Túpac Amaru y se ha fijado en temas de la vida cotidiana, de la situación de la mujer, de la familia y de las costumbres sexuales, sin dejar de plantearse temas globales referidos a la sociedad y la economía. ${ }^{79}$ Siguiendo una tradición de lo que los estudios sobre las actitudes del siglo XVII mostraban, Ward Stavig enfatizó en el uso que los indios hicieron del sistema estatal y legal español, usaron las cortes, apelaron, escribieron al rey y sus asesores. Stavig analizó cómo sólo cuando estos recursos fallaban apareció la violencia, ya desde un artículo de 1988 usa la idea de la "economía moral" ${ }^{80}$ Pero incluso cuando ésta se manifestaba, las protestas eran contra los "abusos" de la ley o la corrupción excesiva, nunca contra el sistema. Por otro lado, las relaciones cara a cara del entramado de poder y cultural rural marcaron las actitudes de los campesinos, que apoyaron bien a Túpac Amaru como al propio corregidor . Stavig no deja de lado las circunstancias políticas generales, la presión fiscal, el aumento demográfico y otras, pero lo cultural tiene en su análisis un papel central.

77 Glave, Luis Miguel: Vida símbolos y batallas. Creación y recreación de la comunidad indígena. Cuzco s. XVI-XX, Fondo de Cultura Económica, Lima/México, 1992.

78 Glave, Luis Miguel: "Sociedad campesina y violencia rural en el escenario de la gran rebelión indígena de 1780” en Histórica, Vol. XIV, núm. 1, Lima, 1990, págs. 27-68. Una versión ampliada fue publicada como "Canas 1780: el año de la rebelión" en Millones, Luis; Hiroyasu Tomoeda y Tatsuhiko Fujii (eds.): Desde afuera y desde adentro. Ensayos de etnografía e historia del Cuzco y Apurímac, Senri Ethnological Reports 18, National Museum of Ethnology, Osaka, 2000, págs. 61-94.

79 Sus varias contribuciones rematan en un libro suyo que es fundamental. Stavig, Ward: The World of Túpac Amaru. Conflict, Community, and Identity in Colonial Perú, University of Nebraska Press, Lincoln, 1999.

80 Stavig, Ward: "Ethnic Conflict, Moral Economy, and Population in Rural Cuzco on the Eve of the Tupa Amaru II Rebellion”, Hispanic American Historical Review 68, 1988, págs. 737-770. 
Por su parte, en un libro que ya mencionamos por su indudable interés comparativo, Nuria Sala i Vila tuvo el acierto de incluir un conjunto de revueltas locales, alzamientos, bullas, motines, que se sucedieron entre la gran rebelión y la coyuntura de 1809-1814. En su libro incluye lo que ella llamó certeramente "la participación indígena en la rebelión de 1814", que considera varias de las asonadas populares que acompañaron el gran levantamiento y que lo continuaron por varios años más. ${ }^{81}$

Como tuve la oportunidad de prologar ese estudio, subrayé entonces algunos casos que trató la autora y que me llevaban a ver en su visión del proceso un mundo de "otras rebeliones" que, sin embargo, parecen estar todas vinculadas con el conjunto mayor del cambio en la sociedad colonial. Entonces comenté el nombramiento del Alguacil Mayor del pueblo de Chincheros en Cuzco en 1820 es una de las tantas escenas que el libro de Nuria Sala nos retrata acerca de las actitudes políticas de los indios. Viene a relación por el motivo del acertado nombre de su libro. En la ceremonia de "entrega de varas", el subdelegado Mariano Campana nombró para el cargo a José Condori. Pero los comuneros de Chincheros habían elegido ellos mismos a Antolín Cusihuamán, a quien Campana llamó indio vejancón y que sabemos era concuñado nada menos que del recientemente derrotado noble rebelde Mateo Pumacahua. Por estas y otras razones el subdelegado recusó la elección de Cusihuamán. Los pobladores contradijeron, sin embargo, la autoridad colonial; bajo el liderazgo de otros ancianos jefes indios entre los cuales Martín Vilca, "indio viejo" y segunda pasado de Ayllupongo - uno de los antiguos linajes de Chincheros: "a una voz habían repugnado los indios, entre los que había habido un murmullo y guri guri que ya parecía principio de tumulto". Por ello el subdelegado detuvo e hizo azotar a los viejos líderes, que en las formas de autoridad interna ejercían un liderazgo alternativo al del mando colonial impuesto al interior de las propias villas y comunidades andinas.

El cura del pueblo afirmaba que la dureza del castigo se debió al temor que este "guri gurí" indio despertaba, con el recuerdo fresco de la guerra de 1814 y el liderazgo ejercido entonces por Pumacahua. También, continuaba el discurso del clérigo, hacía poco, en 1818, en Chalhuanca se habían producido otros sangrientos sucesos. Sabemos que efectivamente varias comunidades del partido de Aymaraes asaltaron el pueblo y asesinaron al subdelegado. El mundo se sacudía, pero, a la vez, se reproducía sin

81 Sala i Vila, Nuria: Y se armó el tole tole... 
llegar a crear un frente, un liderazgo, un programa, que condujera al conjunto hacia algún nuevo destino, mejor o diferente.

Voces múltiples: murmullo, bulla, alboroto, tumulto, asonada, motín parecen indicar una jerarquía de alteraciones, de niveles de intensidad del conflicto social. Sin embargo, las autoridades seguían ejerciendo control, aunque muchas veces sus propias vidas corrieran peligro. Las autoridades indias, por su parte, podían ejercer presión sobre sus competidores no indios o aliarse con alguno de los poderes coloniales para afirmarse sobre la competencia de otros miembros de su propia sociedad, como Condori en Chincheros. ¿Cómo definir ese estado de cosas? El propio testimonio de Campana nos lo dice: un "guri gurí". Sea por la pronunciación del castellano andino, del escribano o del propio Campana, la "o" de gorigori se trasformó en la "u" de guriguri. Gorigori era la "voz con que vulgarmente se aludía al canto lúgubre en los entierros"; por extensión, el funeral al que se asistía era al de la propia sociedad colonial.

Más cerca de considerar las actitudes políticas de los indios y campesinos en la coyuntura de 1809-1824, como lo aportado por Sala i Vila, contamos con David Cahill que por fin ha reunido varios de sus artículos sobre el proceso social, político y cultural del surandino a fines de la colonia. Entre ellos aquel "Taxonomy of a colonial riot" sobre Arequipa en 1780 y el que nos fue de gran interés para el estudio de las actitudes políticas posteriores a la revolución cuzqueña de 1780 , sobre Ocongate en $1815 .{ }^{82}$ Cahill subraya muy a tono con la línea de The Other Rebellion que la dinámica local era diferente y hasta enfrentada a la general de la región. Este autor tiene la virtud de haber desarrollado una investigación que une la coyuntura rebelde de 1780 con los conflictos y la violencia previa a la emancipación política entre 1814 y 1824. Ya en sus primeros estudios, de los que "Curas and social conflict in the doctrinas of Cuzco, 1780-1814" fue el más comentado y con más influencia posterior, Cahill propuso un plan de trabajo que buscaba aclarar el nivel de la participación popular en las protestas, la participación de los campesinos en procesos políticos de naturaleza urbana, si las masas eran instrumentos de la política patricia o en qué grado y con qué contradicciones y si las protestas fiscales por ejemplo fueron el plasma de una ideología popular de más larga duración .

82 Cahill, David: From Rebellion to Independence in the Andes: Soundings From Southern Perú, 1750-1830, CEDLA Latin American Studies, Amsterdam, 2002, págs. 96 y 215. El artículo en referencia es Cahill, David: "Una visión andina: el levantamiento de Ocongate en 1815", en Histórica XII, 2, Lima, 1988, págs. 133-159. 
Según lo rescatado por Cahill, en Ocongate, poblado del entorno rural del Cuzco, tanto los criollos locales como los recaudadores indios, jefes y autoridades del lugar se plegaron a la revolución en 1814. Entre ellos estuvo un indio, danzante y comerciante, llamado Jacinto Layme que a la postre encabezó a los grupos más radicales de los naturales alzados, incluso luego de la derrota del comando revolucionario en 1815. Cuando todavía mandaban en Cuzco los insurgentes, los rumores de una contrarrevolución que preparaban los audienciales recluidos en Paucartambo, provincia vecina de las alturas de Ocongate, llevaron a Jacinto Layme y su hijo a organizar a los indios en acciones contra los criollos locales, entre ellos el alcalde Mariano Dámaso Aparicio, que estuvo involucrado inicialmente en las acciones locales hegemonizadas por los rebeldes cuzqueños. El mismo jefe revolucionario José Angulo mandó a llamar y detuvo a Layme para impedir los enfrentamientos. La contrarrevolución de febrero de 1815 lo halló detenido, pero logró escapar y refugiarse en el Collao donde las acciones subversivas se mantuvieron sin contacto con el cura revolucionario Muñecas u otro caudillo, desarrollando espontáneas iniciativas locales que mostraban un estado de ánimo latente inclinado por la protesta, la revancha y la desobediencia. Otro pueblo cercano, Marcapata, tenía agudas contradicciones internas que llevaron a una explosión popular contra el cura y los criollos, que se desarrolló paralela a la violencia revolucionaria. De la misma manera que en Ocongate, los indios de Marcapata atacaron los símbolos de su explotación, independientemente y luego de la revolución. Layme se sumó a los jefes de Marcapata y luego sumó a esos indios al ataque contra los criollos de su pueblo. Entre los jefes militares indios estuvo "Huamantapara", un indio tenido por principal insurgente de las fuerzas altiplánicas que capitaneaba Ildefonso de las Muñecas. La presencia de Muñecas agitando acciones dispersas y violentas después de la derrota de marzo de 1815 es un hecho poco apreciado por la historiografía de la revolución cuzqueña. Lo mismo ocurre con la presencia esporádica pero recurrente de acciones violentas o de confabulaciones sediciosas por parte de las poblaciones rurales del sur del Cuzco. Durante la revolución, actuaron como focos locales de apoyo y dieron efectivos para las fuerzas que capitaneaba el cacique noble y Brigadier Mateo Pumacahua y otros jefes indios, pero luego actuaron de manera autónoma o dirigida por los restos del ejército que tenían a Muñecas más que como jefe militar efectivo como referente simbólico del mantenimiento de las alteraciones y la protesta indígena. 
Este escenario rural alterado luego de la supuesta pacificación de la región y del reino se muestra en otras situaciones de tensión, violencia y muerte. Un caso que he trabajado en profundidad como un ejercicio de historia cultural y relato microhistórico nos lo muestra. ${ }^{83}$ Este ensayo es una mirada guiada por la nueva historia cultural que analiza los comportamientos de los sectores populares en las movilizaciones políticas que antecedieron a las independencias hispanoamericanas. Pretende escuchar las voces múltiples del pueblo que se alzaron por medio de actitudes, creencias y acciones - individuales y en redes - dentro de un proceso mayor de crisis de representación en el conjunto del estado virreinal. Al analizar las relaciones entre las vivencias del pueblo y los procesos de cambio, ubicamos más certeramente a los actores populares y les damos el protagonismo que viejas visiones políticas o nacionalistas les habían arrebatado. El estudio se centra en un análisis microhistórico de comunidades aymaras del altiplano surandino, con énfasis en el caso paradigmático de un pasquinista llamado Bernardino Tapia. El caso sucedió en 1818 cuando se descubrió una red de relaciones encabezada por Tapia para difundir pasquines en la región de Azángaro - sur del Perú actual- con una inusual forma de entender el proceso político previo a la independencia. Se trata de una época ubicada entre el final de la revolución cuzqueña de 1814 y el inicio de la lucha final por la independencia en 1821-1824. Usamos las formas de análisis historiográfico que se han elaborado para entender la cultura popular en la era de la revolución francesa, particularmente las referidas a los libros, la lectura y la mentalidad que propone Robert Darnton. Ubicamos el lugar de la lectura en una sociedad rural durante una crisis política, tema desconocido e inesperado en la historiografía independentista. ${ }^{84}$

Una sentencia de muerte fue pronuniada en 1819 por el gobernador intendente de la provincia de Puno contra Bernardino Tapia y sus socios por el crimen de alta traición. Se trató de un caso de lecturas, de pasquines, de difusión de un mensaje de desobediencia, de deslegitimación de la monarquía y de soberanía popular. Como tantos otros casos en los que la documentación judicial emanada de la represión de los alzados en 1814 arroja, este de Tadeo Gárate nos vendrá a mostrar un peculiar modo de vivir los nuevos procesos culturales que fueron englobados por el conocimiento

83 Extracto y sigo la presentación hecha en Glave, Luis Miguel: "La ilustración y el pueblo....".

84 Los postulados que surgen del análisis del caso en "La ilustración y el pueblo..." se comparan con los planteamientos propuestos por Eric Van Young y buscan una visión que pueda poner en paralelo los múltiples casos de las sublevaciones hispanoamericanas de 1808-1821. 
posterior como la ilustración, en este caso, una ilustración andina. ¿Las formas de expresión de la ilustración causaron un cambio en las mentalidades populares, o fue que el ámbito cultural del pueblo permitió la difusión y la lectura no letrada, humilde, de la ilustración?

El caso duró un buen tiempo, Bernardino Tapia fue condenado a muerte por la horca y fijación de la cabeza en Azángaro, acusado de alta traición como autor de por lo menos cuatro pasquines que se publicaron en Azángaro, Chupa, Chacamarca y Santaraco, otros que no se llegaron a pegar y confidencias con los insurgentes, particularmente Ildefonso $\mathrm{Mu}$ ñecas. La zona de la acción pasquinista de Tapia corresponde a los pueblos que se ubican a orillas de un pequeño lago que se separa del Titicaca en la orilla norte, en el antiguo territorio de los indios collas omasuyos, en las actuales provincias puneñas de Azángaro y Huancane, territorio donde los líderes de la gran rebelión tupamarista fijaron su cuartel general en 1781. Junto con Tapia, como cómplices fueron condenados 15 indios de los pueblos de Azángaro a azotes y distintas penas infamatorias y de trabajos forzados.

Aunque fragmentarios, los datos nos dan muchas pistas. Así tenemos que durante tres años, entre 1815 y 1818, Tapia actuó como difusor de las ideas seductivas o patriotas, enseñó a leer, mantuvo tertulias, escribió y leyó los libros que compraba con el dinero que se agenciaba con sus enseñanzas o vínculos. Varios de sus allegados fueron soldados en uno u otro bando, algunos fueron revolucionarios y se entrevistaban con él, lo oían y le conferían responsabilidades con sus familias como la enseñanza. Fue hacia 1818, en San Juan, cuando la actividad pasó a la fijación de pasquines que Tapia elaboraba, difundía y pedía que difundan. Y en octubre su accionar se multiplicó y dejó suficientes huellas para que lo apresaran probablemente hacia la quincena pues todavía se reunió con intención de seguir haciendo circular sus escritos hacia el 13. Hasta el 1 de diciembre buscaron cómplices, luego el subdelegado de Azángaro dio por cerrado el caso proponiendo que se disimulara la presión, pues no convenía "alterar los ánimos". Entre las cosas que se desprenden de las respuestas de los implicados es que en el ideario de Tapia y sus allegados se encontraban las reivindicaciones contra el tributo, las alcabalas y los donativos, pero también contra la recluta de gente que era un malestar constante entre los pueblos. También figuraban entre sus acciones verbales el apodar a los leales y españoles con adjetivos denigrantes, probablemente pucacunca que era un término quechua (pescuezo colorado) usado en el campo, pero también 
cotenses o guampos o el más común, chapetones. Eran las denominaciones que recibían los "españoles" en el habla popular, muchas veces cargadas de desprecio o mordacidad. El registro de cotenses o guampos coincide con procesos de desobediencia o alzamientos como los de 1780 o $1814 .{ }^{85}$

La sentencia fue acompañada por las pruebas que consistían en algunos pasquines de puño y letra de Tapia y de dos libros que el autor leía para ilustrarse en sus escritos y alimentar sus sueños insurgentes. Uno de esos libros fue un Tratado de paz contra España y la Francia de 1659 que compró por ocho pesos a un oficial Gallardo. Los pasquines que pegaba Tapia los denominaba "bandos de paz" en relación probable con el tema de este texto. Tapia tenía unas extrañas elucubraciones sobre las relaciones entre Fernando VII a quien llamaba "hijo natural de Murat" —el general francés invasor de España- y un imaginario Carlos V "rey de la patria" cuya "resurrección" apesadumbraba a Fernando VII hasta causarle la muerte. Decía haber leído esta suerte de mito sincrético en las Fábulas de Samaniego que compró por 30 pesos y a las que llamaba Real Seminario Patriótico. ${ }^{86}$

Las fábulas, pues, y las de Samaniego en particular, comprendían un lenguaje que se imbricaba con los discursos preceptivos e iluminadores propios de esa era de cambio cultural que acompañó a la ilustración.

Siempre sacando luz de unos fragmentos, lo que nos quedó de las lecturas de Tapia no fue sólo el libro de Samaniego, también ese curioso "libro" que dijimos llevaba por título Tratado de paz contra España y la Francia de 1659. No era la relación de un suceso cualquiera, 1659 significó el inicio de la decadencia de la monarquía hispana, una crisis de hegemonía en Europa. Lo ocurrido mereció más de una relación de sucesos, nombre de un género literario que antecede al periodismo en la era moder-

85 Ver sobre estos términos Cahill, David: "Colores cifrados: categorías raciales y étnicas en el virreinato peruano, 1532-1824”, en Nueva Síntesis 7/8, Lima, 2001, págs. 29-58, pág. 52. Reproducido en From Rebellion to Independence... Esta agresividad verbal es reconocida también en México en estudios sobre la penalización por desobediencia o subversión, ver Ibarra, Antonio: "Crímenes y castigos políticos en Nueva España, 1809-1816: una aproximación cuantitativa al perfil social de la disidencia política colonial”, en Ibero-Amerikanisches Archiv, 20/1-2, 2000, págs. 163-191. Pero particularmente en Ibarra: "Crímenes y castigos políticos en la Nueva España borbónica: patrones de obediencia y disidencia política, 1809-1816", en Iberoamericana. América Latina-España-Portugal. Nueva Época, II/6, 2002, págs. 27-43.

86 Reminiscencia de los catecismos patrióticos que se difundieron en el Alto Perú. Donoso, Ricardo: El catecismo político cristiano, Imp. Universitaria, Santiago de Chile, 1943. Ver respecto a estos documentos el análisis de Irurozqui, Marta: "La "evangelización” política. Ciudadanía, catecismos patrióticos y elecciones en charcas (1809-1814)", en Debate y perspectivas 3, 2003, págs. 31-54. 
na. Esas relaciones, que hacían vibrar a los pueblos que se agolpaban para escucharlas, se difundían en forma de hojas impresas cuya forma y circulación ha recibido el nombre de literatura de cordel. Colgadas en los cordeles de los puestos donde se vendían productos de feria, los romances eran interpretados por ciegos que tenían un auditorio reconocido en la más extensa geografía de la España y del Portugal de los siglos XVI y XVII. Esa literatura popular, que luego pasó desapercibida por los formadores de cánones cultos, se manifestó explosivamente tanto en España como en América en el siglo XVIII y es sabido el impacto que mantuvo en México del siglo XIX. No conocemos todavía estudios sobre su circulación en el Perú, pero este y otros casos nos muestran que fue, como en todas las otras provincias de ese mismo mundo hispánico americano, una vigorosa forma de difusión de imágenes de la sociedad y de interpretaciones del mundo y de la historia de acuerdo con las lecturas que de ellas se hacían. ${ }^{87}$

De donde en sus lecturas obtendría el seudónimo de Dr. Salas Parrilla de Valdés, en sus pasquines Tapia se decía poseedor de diversos títulos, que difundía en sus conversaciones "seductivas": teniente coronel, comandante general en jefe del ejército auxiliar de la patria, juez teniente, regente mayor, pacificador, conquistador, defensor del Perú, etc. Pero no sólo eso, también afirmaba haber tenido heroicas virtudes al resistir persecución y amenazas, fugitivo y hambriento, pero haber salido triunfante por su sabiduría, coraje, prudencia y otras virtudes. En sus andanzas, plantó sus bandos de paz, como llamaba a sus pasquines, en Azángaro, Puno, Arequipa, Cuzco, Chucuito, Lampa, Sicuani, Carabaya, Huancané, Apolobamba y Larecaja, un ámbito absurdo para las fuerzas de un solo hombre, la mención de esas ciudades se referiría al territorio que tanto Tapia como los rebeldes que coordinaron o siguieron espontáneamente a Muñecas, tenían por zona de descontento e insurrección. Sin pólvora ni avíos, Tapia afirmaba que había gastado 800 pesos y logró, según pensaba, más que los antiguos generales en Buenos Aires y en Cuzco.

Sin duda el mundo onírico de Tapia debió ser capaz de alimentar su resistencia y sus andanzas. Lo que no era cierto es que no hubiese recorrido pueblos en campaña y que ésta proviniese de anteriores contactos del reo con Ildefonso de las Muñecas. Por eso incluye en sus andanzas los territorios donde actuó el cura revolucionario, los que la revolución abarcó y los

87 Una amplia presentación del fenómeno se puede consultar en Glave, Luis Miguel: “Del pliego al periódico. Prensa, espacios públicos y construcción nacional en iberoamérica" en Debate y perspectivas, 3, 2003 págs. 7-30, pág. 13 y ss. 
que en su pequeña patria azangarina había conocido toda su vida. En sus escritos y en sus prédicas, la imaginación andina se cruzaba con un discurso de la patria que se expandió con el ejército revolucionario cuzqueño y de la licitud del rompimiento con España y los españoles.

Tapia había sabido emplearse en los pueblos como profesor de infantes, convencer a algunos adultos de pegar los pasquines que él elaboraba y recordaba entre lo real y el ensueño las hazañas de la lucha de los patriotas. La condena a quince hombres en estos pueblos por distintos grados de "complicidad" muestra que no se trataba de un sueño desquiciado sino de un rumor colectivo, sorda manera de guardar la memoria de la revolución y de imaginar las posibilidades de un mundo diferente y mejor al que se notaba jaqueado desde fuera y desde dentro. Los otros indios que fueron azotados y confinados a trabajos forzosos en el hospital de San Juan de Dios de Puno eran de distintos grados de instrucción. Algunos sabían leer y no pudieron excusar saber el contenido de lo que pegaban, otros no leían pero escucharon las prédicas y las aceptaron. Claro que el argumento del "temor" tenía cierta validez y fue esgrimido casi siempre por los acusados de sedición. Pensaban que si "entraba la patria" serían castigados si denunciaban al profeta. El temor, la sumisión que un sistema de siglos había sembrado en la actitud cotidiana de las gentes, se proyectaba hacia delante. Pero esta razón negativa no desgasta la fuerza de la forma positiva de la adhesión: hablaban, sabían, difundían, "van hacia...", pegaban papeles, en suma, sentían de una manera que se nos hace evidente a través de estos retazos de su pensamiento y de las fuentes que lo informaban. ${ }^{88}$

¿Estaba loco Bernardino Tapia, como pensaba el propio fiscal? Había elaborado una curiosa lectura de la historia en 1818, resucitando a Carlos $\mathrm{V}$ y provocando con ello la muerte del rey Fernando VII que no era sino un

88 Walter, Charles: De Túpac Amaru a Gamarra. Cusco y la formación del Perú Republicano. 1780-1840, Centro Bartolomé de las Casas, Cuzco, 1999, pág. 146, menciona brevemente el caso de Tapia sobre la base del expediente que se conserva en Archivo Departamental del Cuzco, RA, CC, Leg 142, 1819. Comenta Walker otros expedientes de casos donde se arrestaba a gente que borracha gritaba "viva la patria", pero como no se encontraban pruebas de su participación en alguna sedición, se les liberaba, cita al respecto los ejemplos consignados en ADC 1819 y 1820, RA, CC. Las sospechas que partían de palabras o voces eran frecuentes desde hacía muchos años antes. Cornejo Bouroncle da varios ejemplos (Revista del Archivo Histórico del Cuzco 6, pág. 209) como el de 1809 en la causa contra Gabriel Soto, indio del pueblo de Sicuani por verter "expresiones sospechosas contra la tranquilidad pública". Posible rebelión que no se prueba y, sin mayor explicación, se cortan las investigaciones y se libera a Soto. Aunque a algunos se les probó su correspondencia con los rebeldes de La Paz, como a Felipe Rocha, que fue deportado al Alto Perú, había sido tutor de Andrés de Santa Cruz, por lo que Cornejo supone que el futuro presidente vivía un ambiente "libertario" desde su infancia. 
hijo bastardo del general francés invasor Murat. Con ese lío entre onírico y político, justificaba el alzamiento de la patria y de sus líderes, los jefes rebeldes de 1814 y particularmente Ildefonso de las Muñecas, el cura guerrillero que se refugió en los valles y atacó en las punas con su mensaje de no pagar de tributos y de apoyar a las fuerzas insurgentes del Río de la Plata. Entonces los jefes habían muerto, pero la causa seguía viva en el discurso de Tapia. Un discurso que parece perdido, del que no quedan sino retazos, extraídos de algunos pasquines, a los que él llamaba "bandos de paz", inspirado en algunas lecturas. ¿Las lecturas subversivas de la época? ¿Algún escrito perseguido de la ilustración, alguna proclama periodística clandestina, alguna canción popular? Seguro que algo de eso estaba entre sus lecturas, pero lo que quedó palpable, al fin quemado al pie del reo ejecutado fueron sólo las Fábulas de Félix María de Samaniego y un romance que se leyó y reimprimió por varios siglos.

¿Cuánto dijo Tapia de sus lecturas y de sus ideas? ¿Cuánto era ciertamente lo que pensaba y cuánto ocultó? Sus compañeros negaron todo, aseguraron que creyeron que eran insensateces o que tenían temor y por eso no lo denunciaron. Pero en general, el desconcierto del fiscal puede ser el mismo que el nuestro. Esos, como señala Darnton, son los casos que hay que explicar y seguir para entender una sociedad que no tuvo intérpretes ni cronistas. ${ }^{89}$

Tanto en el caso de Azángaro como en todos los que revisé en la vida cotidiana de la ciudad del Cuzco durante los meses de la revolución no encontré muestras de regalismo popular y sí una fuerte carga emotiva y violenta contra los "españoles" entre los que estaban muchos criollos desde luego. El grito de "viva el rey" sonó como consigna justamente el día tris-

89 Robert Darnton en un conjunto de estudios sobre las formas de pensar en Francia del siglo XVIII, las mentalidades desde la gente común, los campesinos que contaban cuentos, los plebeyos que trabajaban en una imprenta, un policía y otros retratos que incluyen páginas de los filósofos de la ilustración, junto a los no ilustrados, renunciando "a la distinción usual entre la cultura elitista y la popular", mostraba que unos y otros "se enfrentan al mismo tipo de problemas". Textos inverosímiles, sorpresa y desconcierto que debieran dejar la gran enseñanza: "cuando no podemos comprender un proverbio, un chiste, un rito o un poema, estamos detrás de la pista de algo importante. Al examinar un documento en sus partes más oscuras, podemos descubrir un extraño sistema de significados. Esta pista nos puede conducir a una visión del mundo extraña y maravillosa". Una cosmología que parece irremediablemente perdida y que para rescatarla, venciendo nuestra incredulidad, la historia cultural no debe "evitar lo raro o preferir lo común" de manera que "apartarse del camino trillado quizá no es una metodología, pero así se tiene la posibilidad de disfrutar de visiones poco usuales, que pueden ser muy reveladoras". Darnton, Robert: La gran matanza de gatos..., págs. 12-15. La edición inglesa original en 1984. También Darnton, Robert: Edición y subversión. Literatura clandestina en el Antiguo Régimen, Turner/Fondo de Cultura Económica, Madrid, 2003. 
te para los rebeldes en que una fulminante contrarrevolución apoyada por la nueva de la derrota militar cambió la hegemonía en la ciudad y debieron huir. Pero decir a partir de ese estudio que no hubo en los Andes muestras de regalismo popular sería incorrecto. El trabajo de Cecilia Méndez es el más cercano al tema que hemos tratado en el caso novohispano. Contrariamente a los textos patriótico-nacionalistas y los críticos de raigambre marxista, que ya incluyeron las perspectivas de Thompson y los de la historiografía francesa de la segunda etapa de los Annales, ella estudió un grupo indígena que levantó las banderas del rey incluso luego de la capitulación del ejército realista en Ayacucho en 1824. En su genealogía del movimiento, no dejó de mencionar que mientras los discursos épicos de las sublevaciones hablaban de independencia y patriotismo, ya alguien, como Jan Szeminski, había señalado que los indios en 1780 habían matado españoles en nombre del rey. Ella ha revisado sus ideas y sus aportes de largos años y acaba de publicar un libro que merecerá más comentario..$^{90}$ Critica el enfoque de Van Young, no niega su valor archivístico pero argumenta contra su enfoque de los campesinos realistas como "milenaristas". Sus ideas sobre la máscara de Fernando y las ceremonias en América sobre la jura de fidelidad al rey, donde aprecia —a pesar de sus observaciones críticas- los aportes de F-X Guerra, ${ }^{91}$ figuran en un capítulo titulado "The People and the King".

Las conclusiones a las que llegan estos trabajos sobre tantas "otras rebeliones" podrían no parecerse a las de The Other Rebellion acerca de la insurgencia mexicana. El mismo Van Young deja abierta esa posibilidad al hacer breves comentarios comparativos con los Andes. Algunos autores, sin embargo, se acercan más a la idea general de Van Young o, sintonizando situaciones concretas, llegan a miradas divergentes. Las herramientas y las perspectivas metodológicas que tienen estos nuevos estudios son, sin embargo, vinculables al derrotero que toma The Other Rebellion. En el caso de los estudios que personalmente he llevado adelante y que he mencionado aquí, comparto las experiencias que expuso Van Young en su polémica con Knight, la lectura de los libros señeros de la nueva historia cultural la hice una vez descubiertas las características de los sucesos, como una necesidad que surgió de la investigación y no como una guía previa a ella

90 Méndez, Cecilia: "The Plebeian Republic: The Huanta Rebellion and the Making of the Peruvian State, 1820-1850”, Duke University Press, Durham and London, 2005.

91 Guerra, François-Xavier: Modernidad e independencias, Mapfre, Madrid, 1992, pág. 156 habla perspicazmente de la "máscara" de Fernando VII. 
que hubiese determinado la selección de fuentes o datos y la separación o silenciamiento de otros. En cualquier caso, la historiografía es una buena manera de ingresar a entender el tema de la cultura política y las actitudes de los actores populares en el proceso de la emancipación. Mucho ha cambiado la visión del proceso en los Andes y es posible acercarse a una visión comparativa con lo más que se ha avanzado en los estudios mexicanistas. Lo que hay que esperar es que estos avances se trasvasen a los discursos más cotidianos y lleguen tal vez a cambiar las visiones de identidad y de futuro que los pueblos latinoamericanos tienen de sí mismos en una era de oscuridad y crisis. No sea que se cumpla la pesimista visión con la que Juan Carlos Garavaglia termina una introducción a una compilación de estudios revisionistas de la Independencia, señalando que "tendremos la ocasión de vernos anegados por una indigesta catarata de loas y panegíricos sobre los padres de la(s) patria(s) que nos sumergirá en montañas de papel, graciosamente pagadas por el contribuyente". ${ }^{92}$ Con menos volumen de papel y páginas mejor escritas, tal vez ganemos la desigual batalla por devolver voces olvidadas y dar pie a que surjan nuevos coros más representativos y justos con su propia historia.

92 Garavaglia, Juan Carlos: "Introducción" a Visiones y revisiones de la independencia..., pág. 19. 